NBER WORKING PAPER SERIES

\title{
CONTAGION OF FEAR
}

\author{
Kris James Mitchener \\ Gary Richardson
}

Working Paper 26859

http://www.nber.org/papers/w26859

\author{
NATIONAL BUREAU OF ECONOMIC RESEARCH \\ 1050 Massachusetts Avenue \\ Cambridge, MA 02138 \\ March 2020
}

We thank conference and seminar participants at the University of California - Berkeley, CEPRBank of Norway, Toulouse School of Economics, University of Colorado-Boulder, Université libre de Bruxelles, the Federal Reserve Bank of Cleveland, and Yale University for helpful comments and suggestions. Joseph Johnson and Fabrizio Marodin provided invaluable research assistance. The University of California at Irvine's Program on Corporate Welfare provided financial support. The views expressed herein are those of the authors and do not necessarily reflect the views of the National Bureau of Economic Research.

NBER working papers are circulated for discussion and comment purposes. They have not been peer-reviewed or been subject to the review by the NBER Board of Directors that accompanies official NBER publications.

(C) 2020 by Kris James Mitchener and Gary Richardson. All rights reserved. Short sections of text, not to exceed two paragraphs, may be quoted without explicit permission provided that full credit, including $\left({ }^{\circ}\right.$ notice, is given to the source. 
Contagion of Fear

Kris James Mitchener and Gary Richardson

NBER Working Paper No. 26859

March 2020

JEL No. E44,G01,G21,N22

\section{ABSTRACT}

The Great Depression is infamous for banking panics, which were a symptomatic of a phenomenon that scholars have labeled a contagion of fear. Using geocoded, microdata on bank distress, we develop metrics that illuminate the incidence of these events and how banks that remained in operation after panics responded. We show that between 1929-32 banking panics reduced lending by $13 \%$, relative to its 1929 value, and the money multiplier and money supply by $36 \%$. The banking panics, in other words, caused about $41 \%$ of the decline in bank lending and about nine-tenths of the decline in the money multiplier during the Great Depression.

Kris James Mitchener

Department of Economics

Leavey School of Business

Santa Clara University

Santa Clara, CA 95053

and NBER

kmitchener@scu.edu

Gary Richardson

Department of Economics

University of California, Irvine

3155 Social Sciences Plaza

Irvine, CA 92697-5100

and NBER

garyr@uci.edu 


\section{Introduction}

Banking panics were a notorious feature of the Great Depression. Friedman and Schwartz famously described the panics, which began in the autumn of 1930, as "a contagion of fear [that] spread among depositors," leading to widespread runs that "had no geographical limits (1963, pp.308)." The runs, according to contemporary observers, forced thousands of banks out of business and forced those that remained in operation to cut lending and increase reserves. It is argued that the changing behavior of depositors and bankers reduced monetary aggregates, depressed prices, raised real interest rates, triggered debt deflation, and lowered consumption and investment (Fisher, 1933; Friedman and Schwartz, 1963), with banking distress featuring prominently in explanations for the length and severity of the contraction in economic activity in the early 1930s (Romer, 1993). ${ }^{1}$

Modern scholars characterize these events in terms of liquidity-preference shocks. Christiano, Motto, and Rostagno (2003), for example, estimate a dynamic, general equilibrium model using interwar United States data and find the contraction of the 1930s was primarily a consequence of a shock that induced households to shift from demand deposits to currency, and that mirror the behavior of deposit-currency and deposit-reserve ratios banks were experiencing (Bordo, 2003). Diamond and Rajan (2006) model how depositors' demands for cash can force banks to sell assets, depress prices and production, incentivize further withdrawals, and trigger contagious bank runs like those that occurred during the Great Depression. Understanding the nature of these events - and in particular whether and how the contagion of fear swept through the financial system and afflicted the rest of the economy - is crucial for understanding the deepest downturn in modern American history as well as drawing lessons from that catastrophic crisis (Bernanke, 2013; Eichengreen, 2016).

Surprisingly, empirical analyses of the effects of the banking panics of the 1930s on lending, the money multiplier, and the money supply surprisingly do not exist for the Great Depression. The contagion-of-fear hypothesis rests on narrative evidence and time-series aggregates collected decades ago. Disaggregated data - such as the location and timing of bank

\footnotetext{
${ }^{1}$ The link between banking panics and the money supply forms a foundation for the monetarist critique of Federal Reserve policies during the Great Depression. While the monetarist characterization of the banking distress of the early 1930s is widely known, scholars have cast doubt on aspects of the account. Wicker (1996), for example, questions Friedman and Schwartz's description of the timing and trigger of the banking panics. Calomiris and Mason (2003a) argue that, during the 1930s, banks failing due to insolvency were, overall, far more important than those due to illiquidity, and that liquidity shocks' role in the Depression was too small to justify a regulatory regime intended to prevent such shocks from recurring in modern times.
} 
runs and monetary aggregates for each of the Federal Reserve Districts - that would have allowed Friedman and Schwartz to test the hypothesis directly were unavailable at the time of their research.

In this paper, we test for two channels through which contagion may have spread from depositors to banks and then to the aggregate economy: (1) via reduced lending activity to households and businesses and (2) via the money multiplier and monetary aggregates. We muster three new data sets and modern empirical methods to quantitatively assess these channels. Two of the data sets are constructed at the level of Federal Reserve districts and frequency of call reports: (1) monetary aggregates (including the money supply, monetary base, and the money multiplier and its components) and (2) the balance sheets of all commercial and mutual-savings banks aggregated by position in the reserve pyramid. These allow us to construct a third, which contains information from weekly-reporting banks aggregated by Fed District that has been corrected for sampling bias inherent in the raw data. Our three new data sets allow us to produce novel estimates of the effects of banking panics on aggregate lending and the aggregate money supply.

Our analysis begins by presenting detailed evidence about when and why banks ceased operating during the Great Depression. We use bank-level data on the causes and timing of bank suspensions to detect banking panics, which we define as periods when depositors changed their behavior en masse and when bank suspensions were highly clustered both in time and space. We then examine how bankers and depositors responded to these spatial and temporal clusters of distress. Our approach enables us to determine when and where contagion took place during the era of bank distress in the early 1930s.

We then assess the impact of these panics on lending and the money supply using a treatment and control estimation strategy. The strategy compares changes in outcomes in Federal Reserve Districts experiencing panics to changes in outcomes in neighboring Fed districts that did not experience panics. We control for common pre-trends as well as differences in Fed policies, real economic activity, expectations, and bank failures outside of panics, all of which vary over time and across Fed districts. Comparing treated and control groups yields causal estimates of banking panics' impact on lending and monetary aggregates, the two channels we identify that transmitted banking shocks to the real economy.

We examine how the balance sheets of banks changed in response to panic-induced deposit flows, particularly the extent to which panics induced banks to reallocate assets away 
from lending to businesses and households and toward the accumulation of reserves. We use a similar empirical strategy, where we account for regional and temporal differences in banking distress, to estimate the direct impact of banking panics on the money multiplier and monetary aggregates. We then aggregate these across Federal Reserve districts and call reports to generate estimates of the total decline in lending and monetary aggregates due to banking panics during the Great Depression.

Our analysis shows that, after the first banking panic of 1930, there was flight to quality. Deposits decreased in districts exposed to that panic but increased in New York City as depositors sought safety from local bank runs. During subsequent panics, as the contagion of fear spread, New York also experienced depositor drains. Using our precisely coded measures of panics periods we show that, from 1929 to 1932, panics reduced aggregate commercial bank loans and investments by $13 \%$ and the money multiplier and money supply by approximately $36 \%$. Banking panics, in other words, caused about $41 \%$ of the decline in bank lending and the and about nine-tenths of the decline in the money multiplier during the Great Depression.

Our research provides an empirical counterpart to theories explaining the existence of bank runs and contagion (e.g., Diamond and Dybvig 1983, Dasgupta 2004) and, more broadly, analyzes how banking distress is transmitted from banks to the real side of the economy. Recent research has shown that economies experience larger and longer downturns when accompanied by financial crises (Reinhart and Rogoff 2009, Jorda, Schularick, and Taylor 2013). Our approach is also consistent with scholarship emphasizing that both recent crises and historical crises have their origins in the financial sector rather than real production (Sims, 2009).

This paper contributes to our understanding of the Great Depression and financial crises, more broadly, by providing a quantitative assessment of two channels through which financial crises are theorized to amplify downturns. ${ }^{2}$ The first is Friedman and Schwartz's wellknown monetary deflation mechanism. ${ }^{3}$ The second is the reduction of lending due to the contagion of fear's impact on the balance sheets of banks. Most banks survived the panics of the early 1930s; however, during these events, the survivors nevertheless lost substantial

\footnotetext{
${ }^{2}$ Bernanke (1983) focuses on the liquidation of banks, which raised the costs of acquiring credit and reduced the supply of loans from banks. The key mechanism transmitting this shock to the aggregate economy was the destruction of relationships and information that facilitated financial intermediation when banks failed. We focus on mechanisms linked to panics and that do not necessarily require banks to fail.

${ }^{3}$ See Friedman and Schwartz (1963), Mishkin and White (2014) for how the Fed's real bills policy and RieflerBurgess doctrine (Meltzer, 2003) constrained Reserve Banks lending through their discount windows during the 1930s.
} 
quantities of time and demand deposits, forcing them to reduce lending to households and firms. This transmission mechanism could alter the quantity and composition of credit, even if it did not change the money supply, the price level, or other aggregate variables that were at the heart of Friedman and Schwartz's (1963) analysis. ${ }^{4}$

Our paper also relates to research assessing the effects of the financial crisis of the Great Recession. ${ }^{5}$ Researchers have noted that, similar to the Great Depression, the 2008 crisis was characterized by contagious runs on financial institutions (primarily investment and shadow banks). ${ }^{6}$ Many of these financial institutions relied on short-term borrowing from the wholesale funding market (rather than the retail market). As in the Great Depression, the demand for liquid assets in 2008 spiked during panic periods as lender behavior changed en masse and creditors became nervous about the quality of the collateral used to support this funding source. ${ }^{7}$ Like non-member commercial banks during the Great Depression, these distressed financial institutions were unable to obtain additional liquidity support from the lender of last resort (the Federal Reserve) due to regulatory prohibitions.

Researchers have also noted how the 2007-8 financial crisis increased bank, firm, and household balance-sheet vulnerabilities. Increasing financial fragility contributed to the decline in consumption and investment spending during the Great Recession (Gertler and Gilchrist, 2018). Finally, our analysis relates to research demonstrating the relevance of balance-sheet constraints as drivers of recessions (Bernanke 2010, 2015, Gorton 2010, Adrian and Shin 2010, and Gertler, Kiyotaki, and Prestipino 2016). Our findings draw attention to the importance of financial-firm balance sheets as drivers of deep and prolonged downturns.

The next section of the paper characterizes the contagion of fear by examining the spread of bank suspensions through time and across space. Section III examines how banking panics effected deposits held in banks, particularly those that survived the events. Section IV examines how panic-induced deposit flows and other factors effected lending by banks. Section

\footnotetext{
${ }^{4}$ Our research also complements earlier studies that have focused on the weakening of household balance sheets during the Great Depression (Fisher 1933, Mishkin 1978).

${ }^{5}$ The two crises share many features, although as our research shows, the precise contours and mechanisms appear to differ in some important respects.

${ }^{6}$ For example, see Gorton and Metrick. (2012) and Gorton (2014) for a description of runs on the repo market, which was used to finance purchases of mortgage-backed securities.

${ }^{7}$ Kacperczyk and Schnabl (2010) and Covitz, Liang, and Suarez (2013) discuss how the asset-backed commercial paper (ABCP) market, which was used to finance mortgage-backed securities, experienced both a tightening of lending standards and a reduction in the supply of credit, causing the interest rate on $\mathrm{ABCP}$ to rise.
} 
V calculates the impact of panic on lending at the aggregate level. Section VI uses the methods described in the preceding sections to estimate panics' impact on the aggregate money supply. ${ }^{8}$

\section{Characterizing Contagion}

The empirical challenge of measuring the contagion of fear is to provide analytical structure to a concept with psychological elements. To do so, we focus on banking panics, periods when fear grips lots of depositors. Banking panics are analytically useful because they are events driven by psychology, but measurable in the data. That is, panics are characterized by periods when bank runs become correlated in space and time due do depositors abruptly changing their behavior and rapidly withdrawing deposits from the banking system (Calomiris and Gorton, 1991).

There are a variety of reasons why depositors initially withdrew their deposits en masse from individual banks during the Great Depression (Calomiris and Mason, 1997, 2003b; Friedman and Schwartz, 1963; Postel-Vinay, 2016). Our empirical focus is not on what triggered a single bank to suspend, but on defining periods when individual bank runs quickly spilled over to nearby banks, leading also to rapid withdrawals in neighboring financial institutions. During panics, depositors can respond to knowledge or beliefs that banks have correlated assets, as in research emphasizing interbank relationships (Diamond \& Rajan, 2006; Allen and Gale, 2000; Freixas, Parigi, and Rochet, 2000; Mitchener and Richardson, 2019), or they may simply believe that other depositors will run their bank, leading to them to withdraw their deposits as well (Diamond and Dybvig, 1983). Thus, to translate Freidman and Schwartz's narrative argument into something observable, we focus on the temporal and spatial correlation of bank suspensions, what we will define as banking panics. ${ }^{9}$

Focusing our empirical investigation on panic periods also helps to pin down the direction of causality when, in Sections IV to VI, we link withdrawals to changes in the lending

\footnotetext{
${ }^{8}$ A series of appendices describes our data, the algebra that we use to calculate the aggregate impact of local shocks, the relationship between monetary aggregates at the national and Fed-district levels, and an extension in which we examine the impact of the nationwide panic in the winter of 1933.

${ }^{9}$ Hypothetically, it is possible that deposit withdrawals became correlated in time and space for some unobservable reason that would be orthogonal to a "contagion of fear" argument; for example, deposit withdrawals might be correlated due to a weather shock or natural disaster. However, as we show later in the paper, because our empirical analysis draws on panics that exhibit substantial variation across Federal Reserve districts and in different periods (Table 1), it is an unlikely that this biases our estimates. To test this further, we dropped each individual panic period and re-estimated our models. Our findings do not appear to have been driven by any single panic episode as the underlying coefficients do not change. We also used examiners statements contained in the micro-level data on individual bank suspensions to understand the nature of suspensions and found no evidence of rapid withdrawals occurring as a result of other types of shocks.
} 
and ratios that affect the money multiplier. During panics, individuals' and firms' willingness to deposit funds in financial institutions shifted suddenly and sizably. Banks reacted to these withdrawals by changing their balance sheets. Using data and techniques described in Sections IV to VI, we measure the impact of changes in demand and time deposit balances on the quantity and composition of lending and on monetary aggregates. During periods without banking panics, when supply and demand for deposits and loans moved gradually and in response to similar stimuli, endogeneity makes it difficult to make inferences based on the data.

Although the U.S. experienced hundreds of bank failures during the 1920s, contagion was limited. That is, few bank failures induced runs on other banks; 14 local panics occurred, but these did not spread beyond a couple of counties (Davison and Ramirez, 2014; Carlson, Mitchener and Richardson 2011). No regional or national panics occurred (Jalil, 2015). However, in the fall of 1930, the situation changed. Bank runs spread rapidly from town to town, city to city, across state borders, and through the interbank network. From the summer of 1929 through the fall of 1930, an average of 15.1 suspensions occurred each week, with a standard deviation of 6.6. In November 1930, just after the collapse of Caldwell and Company, average weekly suspensions rose to 39.1, with a standard deviation of 29.4. Officials at the Federal Reserve Bank of New York recognized the growing problem, noting that "fears of the public found expression in currency hoarding (Federal Reserve Bank of New York, 1931, p. 6)." This period of heightened and variable distress lasted until the Banking Holiday in March 1933.

Scholars have relied on narrative evidence and aggregate time series data on bank suspensions to identify national and super-regional panics during the 1930s (Friedman and Schwartz, 1963; Jalil, 2015; Richardson, 2007a; Wicker, 1996) - events that affected large numbers of banks in multiple, and in some cases, most Federal Reserve districts. More recently, researchers have developed metrics that capture the spatial and temporal clustering of bank suspensions (Carlson, Mitchener, and Richardson, 2011; Davison and Ramirez 2014; Mitchener and Richardson, 2019). These methods can identify local panics that were confined to small geographical areas, such as individual Federal Reserve District, counties, or cities, and which are difficult to detect in aggregate data. We use two of these methods to identify local panics. The Davison-Ramirez procedure identifies clusters of bank suspensions by calculating the number of banks that suspend within (i) a limited distance (measured in miles), (ii) a rolling window (measured in days since the last suspension of a bank within the potential cluster), and 
(iii) a threshold for minimum cluster size. The Mitchener-Richardson method identifies clusters of banks suspensions that exceed those expected if bank suspensions were randomly distributed across banks, time, and space. ${ }^{10}$ This method calculates join counts. A join count indicates the number of pairs of banks that suspended operations within a set distance (measured in miles) and a fixed time interval (such as a week). ${ }^{11}$ Both methods detect all of the panics that Wicker (1996) and other scholars discuss using newspaper articles. We also detect additional panics that were not prominent enough to be appear in newspapers or which were overshadowed by more newsworthy events. Both methods also provide a way to rank the severity of panics relative to each other and relative to the large number of banks failing for other reasons (such as insolvency).

We use geocoded micro data from examiners' reports of bank suspensions to identify geographic clusters of bank suspensions that were collected from Federal Reserve Board archival records described in Appendix A. This database indicates the date and location of all bank suspensions, liquidations, and mergers under duress. ${ }^{12}$ A suspension is defined as a bank closing its doors to depositors for at least one business day, whether temporarily or permanently. The richness of the data is depicted in Figures 1 and 2, which show the suspensions occurring during the Caldwell Panic and in the panic around Britain's departure from gold. The figures also illustrate that national and super-regional panics identified by previous scholarship consisted of scores of regional and local panics occurring simultaneously.

Table 1 shows the distribution over time and across Federal Reserve Districts of bank suspensions in 10-mile, 30-day joins, i.e. banks that suspended within 10 miles and 30 days of

\footnotetext{
${ }^{10}$ Mitchener and Richardson (2019) indicates how to calculate the join count expected under the null hypothesis that bank suspensions were randomly distributed over the landscape, the variance of the null, and the threshold at which to reject the null hypothesis of geographic randomness. Join counts have the additional advantage of explicitly taking into the uneven spatial pattern of banks across U.S. states when calculating panics.

${ }^{11}$ In theory, depositors could run a single financial institution and induce a banking panic. As we are providing an empirical assessment of contagion of fear both methodologies, joins and clusters, will include at least two banks. For clusters, the minimum number in a panic is a parameter set by the researcher. For joins, the minimum panic size is determined by the underlying spatial distribution of the data, the percentage of banks suspending operations during a call interval, and the time interval and maximum distance chosen by the researcher.

${ }^{12}$ The database also indicates the reasons why banks suspended operations (based on examiners' conclusions at the time of suspension), whether banks reopened, and who decided to suspend operations, typically either regulatory authorities or a bank's own board of directors. For certain calculations, we merge this information with data on all banks in operation in the United States on July 1, 1929, as reported in Rand McNally Bankers' Directory. Since this publication provides the town in which each bank operated, we use this information to code the latitude and longitude - information we use when determining whether banks were involved in Depression-era banking panics.
} 
each other. ${ }^{13}$ These clusters are symptoms of local-banking panics (Davison and Ramirez, 2014). Local panics peaked in the last quarter of 1930 and latter half of 1931, during the regional and national banking crises that occurred at those times. Outside these large events, however, many small local panics occurred. ${ }^{14}$ At least one local panic occurred during each call period. At least one panic occurred in every Federal Reserve district. The intensity of these local panics varied. Some triggered the suspension of substantial numbers of banks. Others involved few suspensions. Some occurred close to the border of a Federal Reserve district. These involved only one or two banks in a district but also banks in an adjoining district. A few simultaneously triggered suspensions in all districts. The spatial and temporal variation of the panics identified in Table 1 is crucial to our identification strategy.

The microeconomic data from examiners' reports provides further evidence that bank suspensions, which were clustered in time and space, differed from suspensions at other times. During periods of clustering, examiners commonly reported "heavy withdrawals" or "failure of a correspondent" as the reasons for a bank's suspension. Banks' boards of directors initiated most suspensions, in an attempt to get ahead of the situation and preserve shareholder value. The fraction of banks suspending temporarily (rather than closing permanently) rose. Outside of periods of clustering, examiners more often reported declining asset values as the cause of banks' failures. Regulators were more likely to initiate bank closures. The fraction of banks suspending temporarily fell. Most banks that closed their doors to the public closed them forever. Temporary suspensions are clear indicators of illiquidity since these institutions must

\footnotetext{
13 Table 1 focuses on the definition of clusters that Bayesian econometric methods (described latter in the paper) indicate was most highly correlated with deposit outflows from commercial banks after controlling for other factors. Note that tables based on different definitions of panics (e.g. 30-mile, 10-day, 4-bank clusters or 10-day, 70-mile joins) yield similar patterns. The data shown in the table are aggregated by quarter, which we later match to call dates in order to link them to balance sheet data. For each year, the summer call data fell on the last business day of June, typically June $30^{\text {th }}$. The winter call date fell on the last business day of December, typically December $31^{\text {st }}$. In 1929 , the spring call occurred on March $27^{\text {th }}$ and the fall call on October $4^{\text {th }}$. In 1930, the spring call occurred on March $27^{\text {th }}$ and the fall call on September $24^{\text {th }}$. For 1931 , the spring call occurred on March 26 and the fall call on September 29. For 1932, a spring call did not occur. The fall call came on September $30^{\text {th }}$.

${ }^{14}$ These local panics amounted to nearly $20 \%$ of all bank suspensions from the peak of the business cycle in the summer of 1929 through the Banking Holiday in March 1933. The penultimate row and column of Table 1 indicate that about $20 \%$ of the banks failing during these panics belonged to the Federal Reserve System. The fraction of Fed members caught up in panics rose slightly during the national crisis following Britain's abandonment of the gold standard in the later part of 1931. The last row and columns indicate that, from the summer of 1929 through the Banking Holiday of 1933, nearly 45\% of all banks that suspended operations did so during banking panics. The fraction of banks that suspended during panics (rather than outside of panics) peaked at about two-thirds during the later quarters of 1930 and 1931. The fraction that suspended during panics was highest (from 50\% to 60\%) in industrial northeastern and mid-western states and lowest in states in the south and west. Overall, of the banks that suspended during panics, about $55 \%$ did so during large regional or national events and $45 \%$ suspended during as a result of local panics.
} 
have been solvent. Banks that temporarily suspended eventually repaid depositors, and in most cases, continued to pay dividends to stockholders. From related studies on the Great Depression, we know that in at least some of these incidents, suspended banks that were liquidated eventually had higher recoveries on assets than banks that liquidated outside of periods of panic (Richardson and Troost, 2009). All of this evidence is consistent with the observation that when bank failures were closely clustered in time and space during the Depression depositors withdrew funds from banks en masse.

\section{Examining the Effect of Panics on Deposits}

To understand how the contagion of fear affected banks, we examine two types of data. The first comes from a sample of Federal Reserve member banks (reported to be representative) recorded on Wednesday of each week in about 100 sizeable cities (including all reserve and central-reserve cities). ${ }^{15}$ Weekly-reporting data are aggregates for the twelve Fed districts and the central reserve cities of New York and Chicago. The second type of data comes from call reports. This information is aggregated by Federal Reserve district, level of the reserve pyramid, and call report date - roughly quarterly. Appendix A provides further details on sources and construction.

\section{A. Event Studies on Regional and National Panics Using Weekly-Reporting Data}

The high-frequency, weekly reporting data allow us to use an event-study approach to illustrate how demand and time deposits responded to seven national and regional panics. Our list includes all of the regional and national panics typically identified by economic historians using the narrative method and aggregate data as well as in Mitchener and Richardson (2019), which provides a data-driven approach to identifying larger panics using the aggregate time series data. The panics begin with the failure of Caldwell in November 1930, which triggered runs in Tennessee and surrounding states. Regional and national panics followed in June 1931

\footnotetext{
15 The Federal Reserve reports that weekly reporting banks are a representative sample of all member banks. Participation in the sample is voluntary. When banks cease participating, other banks are recruited to maintain the sample's properties. The Federal Reserve provides little additional information about the nature of the sample. The Fed has not released the identities of weekly reporting banks or details about the sampling procedure. Sample coverage varies from $50 \%$ to $75 \%$ of bank assets over time and across Federal Reserve district. This range indicates that large banks must be oversample, or in other words, that movements in the weekly reporting data largely reflect factors affecting large commercial banks in reserve and central reserve cities.
} 
(a regional panic emanating from Chicago), July 1931 (triggered by the banking crisis in Germany and troubles in Europe), September 1931 (a national panic induced by Britain's departure from gold), a nationwide panic that began in December 1931 and continued through the first week of February 1932, June 1932 (a second Chicago panic), and winter 1933 (the nationwide panic preceding the bank holiday).

Our event studies begin by defining event windows for each panic based upon the criteria described in Mitchener and Richardson (2019). ${ }^{16}$ From the date each panic began, we trace changes in deposits for eight weeks or until the beginning of the next panic. Because panics are defined based upon spikes in the spatial and temporal clustering of bank suspensions relative to trend, it is unlikely that movements of demand or time deposits during these periods (which included large outflows followed by smaller return flows) arose from longer-run trends in the data, such as declining business activity.

Figure 3 plots changes in demand deposits for reporting banks in 100 U.S. cities for the six major banking panics that occurred from 1930 to 1932. Demand deposits dropped substantially during each panic although the magnitudes and precise timing of the decline exhibited some variation. Six weeks after the first banking panic began in November 1930, demand deposits had declined by more than $\$ 300$ million. In the panics in the summer of 1931 and 1932, it took seven weeks for deposits to fall that much. The largest decline in demand deposits, $\$ 800$ million in seven weeks, occurred after Britain devalued the pound in September 1931 and the United States chose to defend dollar parity by raising interest rates.

Figure 4 shows that, during panic periods, time deposits for banks located in 100 cities across the United States also declined. During most panics, the reduction in time deposits was smaller than demand deposits, averaging around \$200 million six weeks after each panic began. This reflects the costs of converting time and savings deposits to cash as well as the fact that these deposits typically formed banks most stable source of funds. Only a small portion of

\footnotetext{
${ }^{16}$ Specifically, banking panics are defined as occurring in spans of consecutive weeks that cross four quantitative thresholds. First, suspensions in each week are above average for the period following the collapse of Caldwell and Company, a key southern banking group that failed during the first large panic of the Depression. Second, for at least one week in the interval, weekly suspensions must be more than five standard deviations above average weekly suspensions for the period of heighted distress after November 1930. In most cases, this five-standard-deviation spike occurred during the initial weeks. All weeks in the interval must have suspensions at least one standard deviation above average. Third, for the entire interval, the proportion of banks closed by a decision of their board of directors, rather than by regulators, must exceed the proportion during the pre-Caldwell period. Fourth, for the entire interval, the proportion of suspensions that examiners attributed to runs, rather than other causes, must exceed the proportion during the pre-Caldwell period. Details of the calculations, data, and replication code appear in Mitchener and Richardson (2019).
} 
time-deposit outflows returned to banks after each panic. Time deposits' return flows were much smaller than those of demand deposits. So, over time, demand deposits increased as a proportion of commercial bank liabilities while time deposits declined. The change in proportions reflected the public's shift toward liquidity. The flight toward liquidity was particularly pronounced in the fall of 1931, when Britain departed from the gold standard, and time deposits quickly declined by $\$ 1$ billion.

Figure 5 plots changes in demand deposits for reporting banks located in New York City. In contrast to the rest of the country (Figure 3), demand deposits flowed into New York's banks during the banking panic of 1930 - as depositors sought safe haven in the country's financial center and away from the origins of the panic in Tennessee and Southeastern U.S. (Wicker, 1996; Richardson and Troost, 2009). During the initial weeks of the panic, demand deposits rose nearly $\$ 175$ million in New York. Demand deposits remained elevated even after the Bank of United States suspended operations on December 11, 1930.

Flows of demand deposits into New York City during the panic of 1930 also prominently appear in Figure 6, which presents data on demand deposits at the Federal Reserve District level. Depositors in New York reacted differently during the next two panics, when deposits flowed out of reporting banks in all Federal Reserve districts including New York City. The difference between New York and the rest of the nation reappeared in the fall of 1931 - when demand deposits again flowed toward New York; however, deposits flowed out again after the Fed raised interest rates to defend the gold standard. In all but the June 1932 crisis, time deposits in New York City banks also decreased in response to banking panics (Figure 7), with the magnitude of the declines (at their low point) varying between $\$ 50$ and nearly $\$ 300$ million. It is interesting to note that, in contrast to demand deposits, time deposits fell in New York City banks during the banking panic in the fall of 1930. This pattern is consistent with the observation that depositors throughout the nation thought of New York as a safe haven and sent their deposits there during flights to liquidity.

\section{B. Panel Estimates using Call Report Data}

As the time-series plots show, the large regional and national banking panics consistently correspond to periods of large outflows of deposits from commercial banks. Did aggregate deposits also decline in response to smaller local and regional panics? What about lending and monetary aggregates? To answer these questions, we construct a new, panel 
database from sources described in Appendix A. The panel contains information from bank balance sheets aggregated by Federal Reserve District for the three tiers of the banking system: country banks, reserve city banks, and central reserve city banks. The panel contains information for all banks, including Fed members, non-member commercial banks, and mutual savings banks. Information exists at each call-report date. The calls were roughly quarterly in frequency. No call took place in the first quarter of 1933, when the national banking holiday was declared, so panel estimates span the period June 1929 through December 1932.

The panel's structure enables us to compare deposit flows in Federal Reserve districts experiencing banking panics to deposit flows in a control group of Federal Reserve districts not experiencing banking panics (or experiencing milder panics). We make these comparisons while controlling for economic and policy factors that influence deposit flows as well as suspensions of banks for reasons other than banking panics. Our new data and empirical approach, therefore, enable us to generate causal estimates of the effects of bank suspensions during the Great Depression.

Using the 15 calls spanning June 1929 to December 1932, we estimate equations of the following form:

$$
\begin{aligned}
D_{i t}= & \sum_{k} \beta_{k} S_{k i t}+\sum_{k} \beta_{k R}\left(S_{k i t} * R_{i}\right)+\sum_{k} \beta_{k C}\left(S_{k i t} * C_{i}\right) \\
& +\varphi X_{i t}+\alpha_{i}+\gamma_{t}+\varepsilon_{i t} .
\end{aligned}
$$

$D_{i t}$ indicates the change in aggregate deposits from call $t-1$ to call $t$ within observations indicated by the subscript $i$. For $i=1, \ldots, 12, D_{i t}$ is the sum of deposits in all country Fed member banks located in Federal Reserve district $i$. For $i=13, \ldots, 24, D_{i t}$ is the sum of deposits in all non-member banks located in Federal Reserve district $i$. For $i=25, \ldots, 36, D_{i t}$ is the sum of deposits in all reserve-city Fed member banks located in Federal Reserve district $i$. For $\mathrm{i}=$ $37, D_{i t}$ is the sum of deposits for all central-reserve-city Fed-member banks located in Chicago. In some specifications, we include observations for all central-reserve-city Fed-member banks located in New York City $(i=38)$. However, given the unique behavior of deposit flows in New York City during panic periods documented in the previous section, we present results focusing on the behavior of bank deposits outside of New York City. We discuss New York City separately later in the paper. In the results section, we present results for time and demand deposits separately. In some specifications, we sum time and demand deposits into a variable 
that we refer to as public deposits. This aggregation is necessary when we report on regression results including non-member banks since we do not separately observe time and demand deposits separately at call dates for them. ${ }^{17}$

The key explanatory variable is the number of bank suspensions. For $i \leq 12, S_{k i t}$ indicates the number of commercial bank suspensions in Federal Reserve district $i$ from call $t$ 1 to call $t$. For $13 \leq i \leq 24, S_{k i t}$ indicates the number of commercial bank suspensions in Federal Reserve district $i-12$ from call $t-1$ to call $t$. For $25 \leq i \leq 36, S_{k i t}$ indicates the number of commercial bank suspensions in Federal Reserve district $i$ - 24 from call $t-1$ to call $t$. For the central reserve cities of Chicago $(i=37)$ and New York $(i=38), S$ is the sum of all bank suspensions in the $7^{\text {th }}$ Federal Reserve District and $2^{\text {nd }}$ Federal Reserve Districts, respectively. The sum of all commercial bank suspensions includes all member and non-member banks operating in central reserve cities, reserve cities, and country locations within the indicated regions. $^{18}$

The number of suspensions, $S_{k i t}$, is also interacted with $R_{i}$, an indicator variable equal to 1 for reserve cities (larger cities whose banks served as correspondents for banks located in other towns and cities). $C_{i}$ is another indicator variable equal to 1 for observations from the central reserve city of Chicago. We distinguish Chicago because it was a central reserve city. Its banks were larger on average than those in other reserve cities and flows in and out of its banks were much larger on average than those in other reserve centers. ${ }^{19}$

In some specifications, we further disaggregate suspensions by type $k=$ \{panic, nonpanic\}. The panic category includes suspensions occurring during events that identified as panics by the methods described in Section 2. The non-panic category includes all other

\footnotetext{
${ }^{17}$ Central reserve city banks are Fed member banks operating in the designated money centers of Chicago and New York City. These banks held the preponderance of the nation's interbank deposits and faced higher reserve requirements than other banks. Reserve city banks are Fed member banks operating in officially designated reserve cities ( 60) spread throughout the United States. Banks in these cities faced higher reserve requirements than country banks, which were defined as all member banks operating outside of reserve and central reserve cities. The Federal Reserve tabulated data for each Fed district at each call report for member banks in these three categories and for all non-member banks (regardless of where they operated).

${ }^{18}$ For robustness, we have run versions of all of these regressions limiting suspensions to just country or just non-member banks. We have also run versions of these regressions where we replace the number of suspended banks with total deposits in suspending banks. We have also run versions of the regression with suspensions in Chicago to suspensions in the $7^{\text {th }}, 9^{\text {th }}$, and $10^{\text {th }}$ districts and where suspensions in New York City equal all banks suspensions in the United States. We have also run versions of these regressions with data on member and nonmember banks pooled together, as in Equation (1), and with the member and nonmember data segregated into two samples. These alternative specifications yield similar results to those reported in the text.

${ }^{19}$ Unlike New York City, deposits flow in and out of Chicago's banks during panic and non-panic periods in the same direction as banks in the rest of the nation. So, it makes sense to keep Chicago in the sample, but allow the magnitude of its coefficient to differ from other reserve centers.
} 
suspensions. The coefficient, $\beta_{\mathrm{k}}$, indicates the average flow of deposits in response to a suspension of type $\mathrm{k}$. The sum $\beta_{\mathrm{k}}+\beta_{\mathrm{kR}}$ indicates the average deposit flow from the reserve cities (or Chicago) associated with suspensions of type $\mathrm{k}$ in that district.

Equation (1) includes additional controls that are meant to capture other influences on time-deposit and demand-deposit flows, including changes in economic conditions and districtlevel Fed policies, which previous scholarship has identified as potentially important. $X_{i t}$ includes (i) the change in the discount rate in effect in Federal Reserve district $i$ from date $t-1$ to $t$, (ii) the change in building permit applications filed between call dates $t$ to $t-1$ and $t-1$ to $t$ 2, and (iii) the change in the Federal Reserve's consumption index, derived from department store sales in each Federal Reserve District, between the month of call $t-1$ and $t$. Fixed effects for each unit are captured by the intercept terms, $\alpha_{\mathrm{i}}$. These fixed effects remove averages for each variable for each geographic unit, yielding the within estimator. Time fixed effects, which are indicated by $\gamma_{t}$, are included in most specifications, except those which include a time trend, which is captured with a $4^{\text {th }}$ order polynomial, $\sum_{p} t^{p}$, where $\mathrm{p}=1, \ldots, 4$. The time fixed effects remove averages for all variables in each period. In each period, in other words, our estimator reveals whether deposits increased (or decreased) more on average in districts experiencing panics that were larger (or smaller) relative to other districts at that time and their own district average over all periods. This approach removes all unobserved shocks that impacted all districts symmetrically.

It does not remove the impact of shocks that impacted a subset of districts but not others or just a district its neighbors. To purge our estimates of such shocks, we replace the geographic and time fixed effects with indicators for each geographic unit and its neighbors in each time period. We add, for example, an indicator for District 1 (Boston) and its neighbor (New York, 2 ) in each time period, plus an indicator for banks in District 2 and its neighbors (1, 3, and 4) in each time period, and so on for all twelve districts. These region/time interactions remove the impact of all shocks effect a district and neighboring districts. The benefit of this approach is reducing potential biases due to unobserved shocks. For example, declining agricultural prices may have influenced banks in some regions of the country more than others. Our estimates now arise from comparing Fed districts that experience panics to their neighbors that do not. The cost of this approach is that it substantially increases the number of variables, reducing the degrees of freedom in our estimates and increasing the standard errors. To balance these costs and benefits, we turn to the literature on model selection in high-dimensional 
settings. We adopt Chudik, Kapetanios, and Pesaran's one-covariate-at-a-time approach (2018). The procedure tests the statistical significance of the net contribution of all potential covariates while taking account of the multiple testing nature of the problem. In our case, this selection procedure leads to keeping all neighborhood effects whose t-ratios exceed a 1.5 threshold along with all of the time-varying district controls and district fixed effects.

Table 2 estimates how demand deposits changed on average when member banks suspended operations between June 1929 and December 1932. Column 1 shows a baseline OLS regression that includes the number of bank suspensions, an indicator for reserve cities, a separate indicator variable for Chicago, and a constant. The estimated coefficient on banks suspensions indicates that each suspension coincided with an outflow of $\$ 165,672$ of demand deposits from county banks located in the suspended bank's district. The corresponding average outflow of demand deposits for reserve cities in the same district as the suspensions occurred is $\$ 140,063$. When suspensions occurred the seventh Federal Reserve district, on average, banks in Chicago experienced a decline of $\$ 91,745$ in demand deposits.

Columns 2-5 display panel, fixed-effects models using a variety of definitions of suspensions and approaches meant to take account of observed and unobserved influences. In addition to the unit fixed effect, all specifications include additional time-varying, district-level control variables. Estimates shown in column 2 control for time-varying factors common across the districts using a polynomial time trend whereas columns 3-5 employ time fixed effects. Columns 6 and 7 use neighbor-time indicators. The inclusion of these variables ensures that our findings are not driven by factors changing over time, including changes in Federal Reserve policies as well as changes in economic conditions or expectations. Standard errors are Huber-White corrected and clustered at the level of Federal Reserve districts and central reserve cities. The inclusion of a polynomial time trend or time-fixed effects (columns 2 and 3) reduces suspensions' impact on demand deposits for county and reserve city banks, but magnifies the impact estimated for Chicago's banks.

To establish that causality runs from panics to deposits, the last two columns of Table 2 separate suspensions into two groups: (1) banks that suspended operations during panics and (2) banks that suspended operations during other periods. Following the discussion in Section 2, column 4 defines the panic group as banks in 10-day, 30-mile joins whereas column 5 defines panics as banks using 4-bank, 10-day, 30-mile clusters using the Davison and Ramirez (2014) 
clustering algorithm. ${ }^{20}$ In these specifications, the non-panic group consists of suspensions not clustered in time and space. Other factors that might influence this relationship, both observed and unobserved, are controlled for with time and district fixed effects as well as data on the discount rate, consumption, and the number of banks suspending operations due to factors other than sudden changes in the public's demand for cash relative to deposits (all of which are timevarying district-level control variables).

In Columns 4 and 5, the coefficients indicate that for each bank suspending operations during a panic, demand deposits for country banks located in the same district fell between $\$ 694,029$ and $\$ 586,151$. In the reserve cities located in the distressed bank's district, demand deposits dropped by $\$ 304,239$ to $\$ 661,108$. In Chicago, demand deposits fell between $\$ 855,371$ and $\$ 970,465$. Estimates with neighborhood effects had similar magnitudes and standard errors.

Importantly, across all specifications shown in Table 2, the estimated effects of suspensions outside of panic periods were uniformly smaller, usually statistically insignificant, and typically had the opposite sign. This indicates that, outside of panic periods, demand deposits often flowed into Fed member banks, although there was a great deal of variation in these flows over time and across districts.

Table 3 presents an equivalent set of regression specifications examining time deposits in member banks. Focusing on the last two columns, for each bank that suspended operations during a panic, time deposits at country member banks located in the same Fed district as the suspension fell from $\$ 772,000$ to $\$ 1,314,000$. In the reserve cities located in that district, time deposits fell by between $\$ 724,000$ and $\$ 1,060,000$, and in Chicago, time deposits fell between $\$ 299,000$ and $\$ 436,000$. These estimated coefficients indicate that, in response to banking panics, time deposits fell by more than demand deposits. This comparatively larger effect likely reflects depositors choosing to move into more liquid assets, or in other words, a flight to liquidity. As we saw in the event study graphs, demand deposits in NYC rose in response to the Caldwell panic, so it is possible that some of the pronounced decline in time deposits was re-deposited in New York banks, at least in the early years of the contraction.

Table 4 presents a similar set of regressions for nonmember banks. For nonmembers, government data sources only provide information for the sum of demand and time deposits,

\footnotetext{
20 These two specifications return the highest inclusion probabilities based on Bayesian model averaging across a wide range of econometric specifications using different definitions of clusters and joins.
} 
which we call public deposits. These sources also sum all nonmembers in each district together, even those located in reserve and central reserve cities. This summation reflects the reality that all banks accepting substantial interbank deposits in central-reserve cities and almost all accepting interbank deposits in reserve cities belonged to the Federal Reserve. Member banks, in other words, had the dominant role in the interbank network whereas nonmember banks did not (Mitchener and Richardson, 2009). Our estimates reflect these institutional features of the data. We find panics associated with large outflows of deposits from nonmember banks. The failure of each bank during a panic corresponded with an outflow of $\$ 2,114,000$ to $\$ 6,675000$ in deposits. Importantly, outside of panic periods, deposits appear to have returned to nonmember banks. The failure of each bank outside a panic window corresponded to an inflow of between $\$ 500,000$ and $\$ 1,000,000$ in deposits. Overall, the evidence from both member and nonmember banks suggests that deposits flowed differently in panics versus non-panic periods.

\section{How did Banking Panics Affect Bank Balance Sheets?}

We now examine how banks' balance sheets changed in response to banking panics. We are particularly interested in whether panics induced banks to alter their portfolios in ways that ultimately reduced aggregate lending to businesses and households, a channel not considered in Friedman and Schwartz (1963) and subsequent research on the Depression. ${ }^{21}$ Banks' balance sheets naturally respond to retail depositor withdrawals. How they did so in the 1930s is an empirical question. Banks could offset declines in deposits with other changes to liabilities, including attracting additional deposits from cash-rich corporations or by borrowing funds from correspondents, other commercial banks, the wholesale money market, or the Federal Reserve. In fact, some Federal Reserve districts expanded discount lending during banking panics, as did the Reconstruction Finance Corporation and other emergency lenders. These reserve banks, however, could not loan sufficient funds to banks quickly enough to offset the massive outflows of deposits during banking panics between the fall of 1930 and the winter of 1933 associated. In some cases, Fed members lacked sufficient eligible paper to borrow the funds that they required. In other cases, non-member banks lacked access to the Fed's discount window. Part of the problem was the competing objectives and economic ideologies of the 12 Federal Reserve Banks, which led them to limit discount lending and raise discount rates even

\footnotetext{
${ }^{21}$ Friedman and Schwartz worked with national aggregates and lacked the data that we are able to use to analyze this channel of transmission to the real economy.
} 
as commercial banks struggled to offset lost deposits (Friedman and Schwartz, 1963; Richardson and Troost, 2009). Since banks could not offset all of their lost deposits by borrowing from other sources, they did so by changing assets. They acquired funds to pay depositors by emptying their vaults of cash, drawing down reserve deposits, calling in loans, or selling loans and bonds.

To determine more precisely how banks responded to depositors' request for payment, we divide member banks' assets into seven comprehensive and mutually exclusive categories:

(1) loans to the private sector

(2) government bonds

(3) corporate bonds

(4) cash and reserves held at the Federal Reserve

(5) interbank assets (a bank's deposits in other commercial banks)

(6) fixed assets such as the value of the bank building plus furniture and fixtures

(7) all other assets.

We then examine how each category changed in response to flows of deposits by estimating seven regressions, one for each category of assets described above. Each regression takes the following form:

(2) $Y_{i t}=\sum_{z d} \delta_{z d} D_{i t z d}+\sum_{z d} \delta_{z d R}\left(D_{i t z d} * R_{i}\right)+\varepsilon_{i t}$,

where $Y_{i t}$ indicates the change from call report $t-1$ to $t$ in dollars of assets in one of the seven categories listed above. $R_{i}$ is an indicator variable for reserve city banks. $\mathrm{D}_{\mathrm{itzd}}$ indicates the change in deposits of type $d$ in direction $z$ from call $t-1$ to $t$ in location $i$. The lowercase $d$ indexes the type of deposit. In some specifications, $d=\{$ interbank, time, demand $\}$. In other specifications, $d=\{$ interbank, public $\}$, where, as noted earlier, public deposits are the sum of time and demand deposits. The letter $z$ indicates the direction of the deposit flow, where $z=$ \{inflow, outflow\}. When the change is positive, the inflow variable equals the change in deposits from call $t-1$ to $t$ and zero otherwise. When the change is negative, the outflow variable equals the change in deposits from call $t-1$ to $t$ and zero otherwise. The coefficients, $\delta_{z d}$, indicate how the number of dollars invested in a type of asset changed when a dollar of deposits flowed in or out of central reserve cities. ${ }^{22}$ The coefficients, $\delta_{z d R}$, indicate how the response to

\footnotetext{
${ }^{22}$ An alternative estimation strategy is to differentiate deposit flows by whether they occur during a panic or non-panic period. Panic periods are those in which the number of panic suspensions in a Fed district during a call period (presented in Table 1) exceed a threshold (such as 1,10, or 20). Non-panic periods include all other observations. This has the advantage of differentiating impacts of deposit flows due to panics from deposit
} 
deposit flows in reserve cities differed from the response in central reserve cities. Since the error terms for the seven regressions are correlated, we simultaneously estimate them using Zellner's (1962) method of seemingly unrelated regressions. Our estimation procedure for nonmember banks is similar, but the data only contain information on loans (category 1 above) and investments (the sum of categories 2 and 3 above). ${ }^{23}$

We simplify the presentation of the results from these regressions in three ways. First, Tables 5 and 6 report linear combinations of the underlying estimated coefficients as well as standard errors and significance levels for these linear combinations. Second, the tables do not report asset categories (6) and (7), for which the coefficients were uniformly insignificant, both statistically and economically. Third, the tables present results for demand deposits, time deposits, or public deposits. ${ }^{24}$

The rows in Table 5 indicate the response to a one-dollar flow of public deposits for member and nonmember banks. For example, when deposits flowed into banks, member country banks increased their loans, cash and reserves, and purchases of corporate bonds. On average, when one dollar of deposits flowed in, loans increased by $\$ 0.22$ in member country banks, by $\$ 0.34$ in member reserve-city banks, and by close to zero in nonmember banks. By contrast, when one dollar of deposits flowed out, loans decreased by $\$ 0.54$ in member country banks, by $\$ 0.35$ in member reserve-city banks, and by $\$ 0.51$ in nonmember banks. Note that positive values for outflows indicate that outflows were associated with reductions in assets, since in the underlying data, outflows are negative numbers. Loans, corporate bonds, cash and reserves, and interbank balances all contracted in response to outflows.

flows due to other causes. It has disadvantages such as the proper choice of threshold (or perhaps multiple thresholds) and additional robustness checks associated with this choice. It is also more difficult to compare to previous research, which uses the inflow-outflow designation. In practice, this alternative specification yields results very close to those presented in this paper. Estimates of coefficients for the impact of deposit flows in panic periods are typically statistically similar to those for deposit outflows presented in this paper. In most cases, statistical tests cannot reject the null hypotheses that the estimates are the same. Our bottom line estimates of the total aggregate impact of panics on lending using this approach change little. Differences across specifications range from about $-0.5 \%$ to $+1.9 \%$. The results are nearly identical because deposits flow out in all panic periods.

${ }^{23}$ Summing corporate and government bonds probably has little impact on our estimates because nonmember banks' holdings of U.S. government bonds changed little from June 1929 (\$786 million) to June 1932 (\$589 million) and June 1933 (also \$589 million) (Board of Governors 1943, p. 23). There are no existing data on categories 4 through 7 . Lack of categories 4 and 5 may inflate the standard errors in our estimation since we link the error terms across estimating equations, but it should not impact the estimated coefficients, given the form of our regressions. Lack of categories 6 and 7 will have little impact on our estimates because banks seldom adjusted fixed assets in response to demands for funds.

${ }^{24}$ Interbank deposits are discussed in detail in Mitchener and Richardson (2019). 
Table 6 separates the impact of time and demand deposit flows on member banks' asset holdings. ${ }^{25}$ Banks invested inflows of time deposits in corporations, either as loans or bonds. Banks invested inflows of demand deposits in more liquid assets, such as bonds, cash, and reserves at the Fed. When time and demand deposits flowed out, member banks curtailed lending to businesses (both direct loans and purchases of corporate bonds). Time-deposit outflows resulted in larger reductions in lending. Demand-deposit outflows resulted in larger reductions in holdings of liquid assets, particularly bonds, cash, reserves at the Fed as well as interbank balances.

Overall, these results indicate that commercial banks accommodated deposit outflows by reducing holdings of corporate bonds and loans to businesses. Repeated panics triggered cycles in which deposits flowed in and out of the banking system. In response, the asset side of banks' balance sheets shifted away from illiquid assets, such as loans and corporate bonds and toward more liquid assets, particularly cash and reserves at the Fed.

\section{The Aggregate Effects of Panics on Lending, 1929-32}

The results from the previous section allow us to quantify the change in lending due to banking panics, denoted L, across all periods and all Federal Reserve Districts. It is computed as the product of: (i) the number of bank suspensions during panic periods; (ii) the estimated deposit outflows triggered by suspensions during periods of panic; and (iii) the estimated decline in lending associated with those deposit outflows. Thus,

(3) $\quad L=s^{\text {panic }} B_{1}^{\text {time }} \delta^{\text {time }}+s^{\text {panic }} B_{1}^{\text {demand }} \delta^{\text {demand }}$

where $\mathrm{s}^{\text {panic }}$ is a 1 x 12 vector, indicating suspensions in Federal Reserve Districts 1 through 12 during panic periods. Using the notation from Equation (1), the $i^{\text {th }}$ element of this vector is $s_{i}^{\text {panic }}=\sum_{t} S_{i t}^{\text {panic }}$, or the sum of suspensions during panics in the $i^{\text {th }}$ district from period periods 1 to T. $B_{1}^{\text {time }}$ and $B_{1}^{\text {demand }}$ are 12 × 38 matrices, whose elements indicate how suspensions during panics in district $I$ influenced flows of demand and time deposits into and out of banks in district $j$. For member banks, estimates of these parameters appear in Tables 2 and 4. For nonmember banks, estimates appear in Table 4. Details of the matrices' structures appear in Appendix B. $\delta$ is a 38 x 1 vector that indicates how deposit outflows impacted lending and investing by commercial banks. It is superscripted to distinguish between time and demand

\footnotetext{
${ }^{25}$ As noted above, we do not have disaggregated time and demand deposit data for non-member banks.
} 
deposit outflows. For nonmembers, we report these values in Table 5, panel B. For member banks, we report these values in the bottom half of Table 6 .

In the first five columns, standard errors are bootstrapped using the standard panel (or block) bootstrap (Cameron and Trivedi, 2005). For each model, we resample with replacement 10,000 times over $i$. For each sample containing at least one of each type of unit of observation (i.e. at least one $i<13$, at least one $13 \leq i \leq 24$, and at least one $25 \leq i \leq 37$ ), we estimate Tables 2 through 6, calculate changes in lending, and then calculate the distribution of those estimates. ${ }^{26}$ In columns six and seven, we cannot use a bootstrap procedure to calculate the standard errors for the reasons described by Catteneo, Jansson, and Ma (2019). The model in the first stage of our two-stage calculation is saturated. The number of regressors is large relative to the sample size. So, we calculate the standard errors using the Jackknife procedure that they recommend.

The total decline in lending due to banking panics is reported in Table 7. The estimated decline for member banks between July 1929 and December 1932 ranges from \$1.7 billion to $\$ 3.5$ billion. The estimated decline for nonmember banks ranges from $\$ 2.4$ billion to $\$ 3.9$ billion. Estimates for all banks range from $\$ 5.2$ billion to $\$ 7.1$ billion. The last column presents a Bayesian average over all possible permutations of all the models that we have estimated. That average indicates that panics reduced lending by $\$ 6.4$ billion - an amount equivalent to $13 \%$ of the $\$ 49.4$ billion of loans and investments on bank balance sheets in the summer of 1929 and $41 \%$ of the decline in total bank loans and investments between the summer of 1929 and the end of 1932. It is roughly double the $\$ 3.3$ billion in loans and investments trapped in failed banks over that period (Richardson 2007a, 2008), and it is nearly five times the $\$ 1.3$

\footnotetext{
${ }^{26}$ This method, which is explained further in Mitchener and Richardson (2019), provides reasonably precise standard errors when we assume the average response in the city of Chicago was the same as the average response in reserve cities throughout the United States (as indicated in equations (2) and (3)). It does not work well, in theory or in practice, when estimate separate slopes and intercepts for Chicago, because then we need to exclude from the resampling all data sets that do not include Chicago; this dramatically alters the resampling pool resulting in standard errors that are large and which, in theory, need not be consistent. To overcome this technical issue, we have re-estimated all of the empirical work in this paper using a Bayesian method that does not suffer from this problem. Our Bayesian method yields coefficients and aggregate estimates that are statistically indistinguishable from those in this paper and credibility intervals that are smaller, particularly in the Chicago case described in this paragraph. We have also recalculated all of our estimates where we treat Chicago as the same as all other reserve cities, but where we give that city its own intercept and slope. This specification has almost no impact on our aggregate estimate. We have created an online appendix with computer code and additional information about this technical issue, which although time consuming for us to explore, proved of little practical importance in terms of our central findings. Hence, the paper reports estimates in a similar way to previously published work.
} 
billion decrease in lending due to the contraction of interbank networks over that span (Mitchener and Richardson, 2019).

Our estimates may understate banking panics' impact on aggregate lending because they presume that panics did not directly reduce aggregate lending by New York City's banks between June 1929 and December 1932. This presumption is a reasonable first approximation for several reasons. First, when panics occurred outside of New York in 1930 and the fall of 1931, deposits flowed into New York City banks. When panics occurred outside of New York City at other times, deposits flowed out of New York City banks. These contrasting flows partially cancel each other out. Second, while panics outside of New York City were correlated with deposits and lending in Manhattan's money-center banks, bank failure rates inside New York City were not. Third, few large banks failed in New York City. Resolutions of those that did fail were expedited by transferring much of the deposits of the failed banks to banks that remained in operation. Fourth, data constraints make it difficult to deal systematically with the evolving impact of panics on demand deposits in New York City. Our panel contains 14 observations for New York City over the period of interest. From this small sample, we cannot precisely estimate coefficients whose magnitude and sign change over time. ${ }^{27}$

The assumption that panics had little impact on lending in New York biases our aggregate estimate downward. Total loans and investments at banks in New York City declined by roughly \$1 billion from June 1929 to December 1932 (Board of Governors 1943, p. 36). These declines were due in part to the changing quantity and use of interbank deposits (Mitchener and Richardson, 2019; Richardson and Van Horn, 2018). Another substantial portion of these declines were due to banks shifting to more liquid portfolios to prepare for runs that they feared might arise (but did not occur until the winter of 1933). Our methods cannot determine how much of the rest was due to the immediate impact of panics. If we assume that lending declined due to panics at the same rate in New York City as in the rest of the nation, then our estimates for July 1929 to December 1932 would increase by the amount and percent indicated in Table 7, which ranges between from $1.7 \%$ and $2.3 \%$.

\footnotetext{
${ }^{27}$ We believe that the coefficients should change over time because of the patterns in data from weekly reporting banks that we presented earlier in this essay. We can incorporate the weekly reporting data into our aggregate calculations, because it lacks some information and a consistent sampling procedure that our methods require.
} 


\section{Banking Panics, the Money Multiplier, and the Money Supply}

The most influential insight concerning the Great Depression in Friedman and Schwartz's Monetary History is that the Fed's failure to act allowed banking panics to reduce the money multiplier, money supply, and price level. ${ }^{28}$ The resulting deflation transformed what had been a severe contraction into the Great Depression. This insight influenced macroeconomic thinking and central bank practices from the 1960s to the present (Ben Bernanke 2005, 2013). Its power stemmed, in part, from the logic underlying Friedman and Schwartz's argument and in part from their convincing analytic narrative, which emphasized the chronological connection between banking panics and changes in monetary aggregates.

How much did the banking panics reduce the money supply? Friedman and Schwartz present a range of answers. Their low-end calculation of $17.2 \%$ represents the total decline in the money supply that occurred during the three banking panics at the center of their narrative methods (Friedman and Schwartz 1963, pp. 342, 346-347, and 712-714). This amount, however, ignores the impact of banking panics on the money supply outside of those three episodes. Their high-end calculation of $48.5 \%$ is based on the amount the money supply would have declined from the summer of 1929 through March 1933, given the decline in the money multiplier and if the monetary base had remained constant. Of course, this figure overstates the impact of the banking panics because it ignores factors like the declining demand for money and credit, which may also have lowered the money multiplier, and which may have occurred due to the economic contraction even in the absence of banking panics (Friedman and Schwartz 1963, p. 349). Friedman and Schwartz conclude that a reasonable conjecture splits the difference between upward and downward biases and thus falls somewhere between $31 \%$ and $33 \% .^{29}$

Because their analysis preceded the development of modern econometric methods and the discovery of many data sources, there is scope for improving upon their conjectures. ${ }^{30} \mathrm{We}$

\footnotetext{
28 "Given the policy followed by the Reserve System, the failures were the mechanism through which a drastic decline was produced in the stock of money... the losses produced by bank failures were minor and would deserve no more attention than losses of a comparable amount in, say, real estate." (Friedman and Schwartz, 1963, p.351).

${ }^{29} 31 \%$ represents the money stock's decline from August 1931 to January 1932 as a percentage of the stock of money in circulation before the contraction began in August 1929 (Friedman and Schwartz 1963, p. 349). 33\% is discussed in multiple locations (Friedman and Schwartz, 1963 pp. 299, 301-2, 353)

${ }^{30}$ Note: after one of the authors, Gary Richardson, discovered in the National Archives the bank failure data that we use as an explanatory variable in our estimates, he corresponded with Milton Friedman, who said that he and Anna Schwartz had looked for the information, but could not find it. He suggested that we use it for an analysis along lines similar to those that we present here.
} 
do this by first recognizing that the twelve Federal Reserve banks operated independently prior to the creation of the Federal Open Market Committee. Each Federal Reserve bank had its own balance sheet, gold reserve, and Federal Reserve notes. The Federal Reserve System had a mechanism for returning notes that circulated outside each district to the bank that issued the notes and for shifting gold between Reserve Banks to accommodate these inter-district flows. Thus, each Federal Reserve district had its own money supply from which we construct monetary aggregates using methods and data similar to those that Friedman and Schwartz used to calculate national monetary aggregates. ${ }^{31}$ These new data allow us to compare changes in monetary aggregates in Federal Reserve districts that suffered banking panics at a particular point in time to changes in monetary aggregates in Federal Reserve districts that did not.

We can, in other words, re-examine Friedman and Schwartz's concept of the contagion of fear using modern panel-data methods. We do this by estimating equations of the form:

$$
\Delta m_{i t}=\alpha_{i}+\gamma_{t}+\sum_{k} \beta_{k} S_{k i t}+\varphi X_{i t}+\varepsilon_{i t}
$$

Variables introduced earlier retain their definitions. We define a new variable, $m_{i t}$, as the money multiplier in district $i$ at date $t . \Delta m_{i t}$ is the change in the multiplier from call $t$ - $l$ to $t$. The subscript $i$ indicates the $i^{\text {th }}$ Federal Reserve district for $i=1, \ldots, 12 .{ }^{32} \mathrm{We}$ assume that bank failures in district $i$ change the money multiplier only in district $i$ at time $t$. This assumption fits the data well. We tested for leads, lags, and cross-district effects and found neither economic nor statistical significance. In most specifications, we also assume that the impact of bank suspensions of type $k$ (panic or non-panic) on the money multiplier is the same across time and space, after extracting average changes in each period and district (i.e. time and district fixed effects). As assumption like this is necessary for identification, and it fits the data well for ten of the twelve Federal Reserve districts. However, two districts behave differently. One is the $6^{\text {th }}$ district headquartered in Atlanta. It is the only district whose money multiplier does not fall during the Depression. It does, however, experience regional panics, including the panics in Florida in the summer of 1929 (before the Depression began) and Tennessee and Mississippi

\footnotetext{
${ }^{31}$ Appendix A describes how we construct monetary aggregates for each Federal Reserve district.

32 The upper layers of the reserve pyramid, which previous equations denote $i=13, \ldots, 26$, do not appear in this regression, since historical sources and institutional features only allow us to construct monetary aggregates (such as M2, M3, monetary base, and money multiplier) at the level of the Federal Reserve district. We cannot calculate money supply for different layers of the reserve pyramid, or for different types of banks, or for particular cities.
} 
in 1930. Its fit with our model is poor, but this has little impact on our aggregate estimate because the district accounts for a small fraction of the aggregate money supply. The other anomalous Federal Reserve District is the $7^{\text {th }}$, Chicago, which we discuss in more detail below.

We estimate equation (4) using Bayesian model averaging (BMA). Details of this procedure are discussed in an online appendix. ${ }^{33}$ BMA prefers a model including the full range of time-varying controls for economic activity and Fed policies, time and district fixed effects, and banking panics defined using 4-bank, 10-mile, 30-day clusters of suspensions. Coefficients on these variables have the expected signs. For example, when consumption falls, the money multiplier rises. This finding is consistent with the standard theory of the transactions demand for money. When households and firms conduct fewer transactions with cash, they demand less currency. The quantity of currency in circulation falls. The share of the public's funds held in banks increases and the money multiplier rises. On average, for each bank that failed during a panic, the money multiplier in that bank's Federal Reserve district during that call period changed by -0.034 . Outside of panic periods, there is no consistent correlation between bank failures and changes in the money multiplier. There also appears to be no consistent correlation between banking panics in one Fed district and declines in multipliers in other districts, including nearest neighbors, or between panics in a call period and declines in multipliers in later periods. We test for these spillovers as well as for lags, but their inclusion probability in the BMA is low (near zero). Similarly, in standard classical regression specifications, we cannot reject the null hypothesis that coefficients on lagged effects and spillover variables are zero.

The impact of banking panics on the money multiplier at the national level, $\widehat{m}_{t}$, can be calculated as:

$$
\widehat{\Delta m}_{t}=\sum_{i} \widehat{\Delta m}_{i t} b_{i, t-1}=\sum_{i}\left(\beta_{\text {panic }} * S_{\text {panic }, i t}\right) b_{i, t-1},
$$

\footnotetext{
${ }^{33}$ We run our BMA analysis in two stages. The first stage is model selection. We run hundreds of model combinations using all different measures of panics and different combinations of controls each time. We select the measure of banking panics with highest posterior probability (e.g. Joins 10 miles - 30 days). The second stage is model averaging. We pick the measure preferred by the first stage (e.g. Joins 10 miles - 30 days) and rerun the procedure with all possible different combinations of controls. We then use the "averaged" beta coefficient obtained in this stage in all the table calculations. In practical terms, the beta coefficient is very similar to the one obtained in the first stage, which is also averaged; however, in the second stage we include a larger number of combinations of controls: in fact, we include all possible controls. We do not include all possible combinations of controls in the first stage to make the procedure simpler and faster to run. Overall, we are choosing the specification with highest posterior probability as well as averaging across specifications that differ based on control variables.
} 
where $\widehat{\Delta m}_{i t}$ indicates how much banking panics reduced the money multiplier of Federal Reserve district $i$ from call $t-1$ to $t$, and $b_{i, t-1}$ indicates district $i$ 's share of the aggregate monetary base at the beginning of the call period. ${ }^{34}$ This share determines how much the national money multiplier responds to the change in the multiplier of a particular district. $\beta_{\text {panic }}$ indicates the decline in a district-level money multiplier due to a bank suspension during a panic in that district, which we estimate via equation (4). $S_{\text {panic, it }}$ indicates the number of suspensions due to banking panics in Fed district $i$ between call $t-1$ and $t$. Appendix $\mathrm{C}$ derives equation (5). Calculations of $\widehat{\Delta m}_{t}$ for the summer of 1929 through the winter of 1932 appear in Table 8.

Column 2 of Table 8 shows quarterly changes in the national money multiplier based on our calculations. It closely tracks changes reported by Friedman and Schwartz. ${ }^{35}$ Column 3 shows that panics changed the national money multiplier in every call period. The estimate is always negative because the money multiplier always fell during panics and because we detect at least one panic in at least one Federal Reserve district during each call interval. The size of the decline in any period varies according to the intensity of the panics. Some periods witnessed small, localized events restricted to single, peripheral districts. These events contributed little to changes in the aggregate money multiplier. In other periods, panics involving a large number of banks occurred in districts that provided a substantial share of the nation's total money supply, like the Chicago panic June 1931. These events had a large impact on the aggregate multiplier.

We calculate an uncertainty interval around our estimate by bootstrapping. We create 1,000 data sets by resampling with replacement over the 12 Federal Reserve Districts. Then, for each simulated data set, we use our BMA procedure to re-estimate equation (5). The distribution of these new estimates yields our uncertainty interval. The uncertainty interval includes the range of estimates that Friedman and Schwartz believed to be reasonable conjectures. The interval includes the conclusion that the decline in the money multiplier was

\footnotetext{
${ }^{34}$ In our notation, call periods begin at $t-1$ and end at $t$.

${ }^{35}$ While we use the same data sources, small differences exist between our estimates and Friedman and Schwartz (1963). These differences arise for several reasons. One, F\&S provide monthly estimates of monetary aggregates. They do this by interpolating information about aggregate bank-balance sheets between call report dates. We do not do this. Instead, we report and analyze information from call report dates. Two, F\&S seasonally adjust their estimates by extracting from the money supply for each month its typical deviation from the annual average and reporting aggregate variables excluding this seasonal component. We do not do this. Instead, we work with unadjusted figures. Readers should note, however, that our regression do control for time fixed effects, which extracts seasonal patterns from variables before estimating coefficients.
} 
due entirely to banking panics. The interval excludes the opposite conclusion: that panics had no impact on the multiplier. The interval's width is wide, stemming from the fact that our model does a poor job of predicting changes in the multiplier in Atlanta and Chicago. Atlanta is the only district whose multiplier does not decline between 1929 and 1932. A simulated data set that heavily weights Atlanta, therefore, yields estimates different from other districts. While Chicago's multiplier declines between 1929 and 1932, it rises substantially during the first few call intervals of the contraction. Chicago is the only district that has large increases in the money multiplier in some call intervals, typically those without panics. Chicago has even larger declines in the money multiplier during other call intervals, particularly those with panics. So, a simulated data set that heavily weights Chicago yields estimates different than the other districts. $^{36}$

Movements in the money multiplier in 1929 and 1930 highlight issues raised by Friedman and Schwartz. The multiplier moved up in some quarters and down during others as seasonal and cyclical factors influenced banks' portfolio choices, firms' borrowing behavior, and households' cash-holding decisions. Before large banking panics began, local panics had less influence on the multiplier than other economic forces. After large banking panics began in the fall of 1930, nearly all of the decline in the money multiplier was due to banking panics. On the last call date before the onset of the contraction in the summer of 1929, the money multiplier stood at 6.62. From June 1929 through December 1932, we observe a decline in the multiplier of 2.53. We estimate that panics alone would have caused a decline of 2.32. In other words, $91.5 \%$ of the decline in the multiplier was due to the banking panics.

We reach a similar conclusion for the money supply. On the last call date before the onset of the contract, June 29, 1929, the aggregate money supply in the United States stood at $\$ 46,693$ billion. The money supply declined to $\$ 35,188$ billion on December 31,1932 . Column 3 of Table 8 indicates the change in the money supply from one call report to the next, which we denote $\widehat{\Delta M}_{t}^{\text {actual }}$. The fourth column indicates the change in the money supply due to banking panics. We calculate this amount, denoted $\widehat{\Delta M}_{t}^{\text {panic }}$, with the formula:

$$
\widehat{\Delta M}_{t}^{\text {panic }}=\sum_{i} \widehat{\Delta m}_{i t} B_{i, t-1}=\sum_{i}\left(\beta_{\text {panic }} * S_{\text {panic }, i t}\right) B_{i, t-1}
$$

\footnotetext{
${ }^{36}$ Chicago's multiplier rises in periods when currency in circulation declines, but deposits remain steady. This could be occurring for several reasons, such as inter-district deposit flows. We lack sufficient data and documentation, however, to ascertain the cause. The unique behavior of Atlanta's multiplier appears to be driven by Atlanta's unique policies. We explore this issue in a subsequent essay.
} 
This calculation reveals the impact of banking panics on the money supply when $B_{i, t-1}$, the monetary base in district $\mathrm{i}$ at call date $\mathrm{t}-1$, is held constant. The fifth column indicates the change in the money supply due to changes in the monetary base assuming the money multiplier remained constant. We calculate this amount, denoted $\widehat{\Delta M}_{t}^{\text {monetary base }}$, with the formula:

$$
\widehat{\Delta M}_{t}^{\text {monetary base }}=\sum_{i} m_{i, t-1} \Delta B_{i t}
$$

where $m_{i, t-1}$ is the monetary base in district $\mathrm{i}$ at call $\mathrm{t}-1$, and $\Delta B_{i t}$ is the change in the monetary base in district $\mathrm{i}$ from call $\mathrm{t}-1$ to $\mathrm{t}$. The last column in Table 8 indicates changes in the monetary base for all other reasons. It is calculated with the formula

$$
\widehat{\Delta M}_{t}^{\text {other }}=\widehat{\Delta M}_{t}^{\text {actual }}-\widehat{\Delta M}_{t}^{\text {panic }}-\widehat{\Delta M}_{t}^{\text {monetary base }}
$$

Our estimates for the money supply resemble those for the money multiplier. Panics explain the decline. If the monetary base had remained constant, depositors' and bankers' responses to panics would have reduced the money supply by $\$ 17$ billion by December 1932 , a decline of $36 \%$. Our analysis confirms Friedman and Schwartz's conjecture: banking panics reduced the money supply substantially - with our estimates putting their contribution at more than $35 \%$. The observed decline in the money supply was $\$ 12$ billion because the negative effect of the panics on the money multiplier was partly offset by expansion of the monetary base, which grew from \$7 billion to \$8 billion between the summer of 1929 and end of 1932 . That said, the monetary base would have had to expand by much more, to $\$ 11$ billion by the end of 1932, to have kept the money supply constant at the pre-Depression level. It is worth noting that the roughly $60 \%$ expansion that would have been required to keep the monetary base constant from the last quarter of 1929 to December 1932 is substantially smaller than the over $200 \%$ expansion in the monetary base that policymakers enacted following the failure of Lehman Brothers in 2008 during the Great Recession.

The impact of banking panics on monetary aggregates can also be put into perspective by comparing preceding economic contractions to the Great Depression. The 1920-21 recession was short, lasting only 18 months, but severe. During that span, industrial production contracted as rapidly as in the first 18 months of the Great Depression; however, no banking panics occurred. From NBER peak to trough, the money supply declined by only five percent. The 1907-8 contraction lasted for 13 months. Industrial production also declined substantially, although less than in 1920-21 and 1929-33. A short (three weeks) and severe banking panic swept the nation, and from NBER peak to trough, the money supply declined by seven percent. 
Our estimates suggest that if banking panics had not occurred during the 1930s, the money supply would have declined by three to four percent, or roughly the same percentage as during the contraction a decade earlier. This decline would have been entirely offset by the Fed's expansion of the monetary base. The difference between 1920-21 and 1929-32, in other words, stemmed from the liquidity-preference shocks of the early 1930s and their impact on monetary aggregates.

\section{Conclusion}

Friedman and Schwartz famously argued that panics spread a contagion of fear with "no geographic limits" throughout the nation, triggering changes in depositors' and bankers' behavior spanning several years, which in turn triggered declines in the money multiplier and money supply (Friedman and Schwartz 1963, p. 308). However, their path breaking research did not quantitatively estimate the effects of panics on the money supply or on aggregate lending.

Our analysis, based on new data on the location and timing of individual banks suspensions and new data on balance sheets and monetary aggregates for all banks in each Federal Reserve district, suggests the contagion of fear's scope was bounded, both in time and space. Consequential banking distress occurred during panic periods, characterized by temporal and spatial clustering. Depositors suddenly changed their behavior during panics and withdrew their funds en masse, a particular useful feature for identifying deposit withdrawals that were unanticipated. We demonstrate that these banking panics led to a significant contraction in real economic activity through two channels: (1) declining monetary aggregates (as first discussed by Friedman and Schwartz) and (2) a contraction in lending to firms and households by surviving banks. At least one-third and up to one-half of the total decline in commercial bank lending occurred after panics induced depositors to withdraw funds, forcing surviving banks to reduce loans and investments. Further, almost the entire decline in the money multiplier occurred in Fed districts when they experienced banking panics.

Our research builds a bridge between earlier scholarship on the Great Depression emphasizing monetary forces with more recent DSGE models and VAR representations of this era. For example, Christiano, Motto, and Ristango (2003) have characterized a substantial share of the decline in money, prices, output, and employment as arising from liquidity-preference shocks, beginning in the fall of 1930 and lasting through the winter of 1932. Our new evidence 
on the nature and consequences of the banking panics of the early 1930s provides one interpretation of what these liquidity preference shocks were. Local banking panics occurred periodically during the 1920s. In 1929 and 1930, their frequency and magnitude increased gradually, until the fall of 1930, when the number of afflicted districts and the size of the shocks increased markedly. The spread abated in the summer of 1932, before resuming with vigor in the winter of 1933. Our results indicate that these local shocks substantially reduced bank lending and monetary aggregates. Banks' loans portfolios and the money multiplier contracted in Federal Reserve districts during quarters that they experienced banking panics.

Understanding the nature of contagion helps us to judge proposals for policies that could have alleviated the Depression. Many scholars have argued that the Federal Reserve could have and should have offset the decline in the money multiplier by aggressively expanding the monetary base (Friedman and Schwarz, 1963; McCallum, 1990; Bordo, Choudhri, and Schwartz 1995; Christiano, Motto, and Ristango, 2003). Other scholars questioned the feasibility of these proposals. A principal constraint discussed in the literature is the gold standard, which tied policymakers' hands intellectually and legally, particularly in 1931, when the New York Fed raised interest rates to reduce gold flows from the U.S. and in 1933 when the New York Fed approached the legal gold constraint (Eichengreen 1995). However, the majority of the decline in the money supply occurred in Federal Reserve districts like Chicago, which experienced repeated banking panics and also retained large stocks of free gold (and thus the ability to expand the monetary base) throughout the contraction.

Our research thus suggests that policies aimed at mitigating these panics or diminishing their influence on the behavior of depositors and bankers may have reduced the decline in the money supply. Given the decentralized power structure of the Fed in the early 1930s as well as disagreements within the Board over monetary policy on how to respond to banking distress (Meltzer, 2003; Wood, 2005), responses at the Federal Reserve district level may have been more feasible. Indeed, leaders of some Federal Reserve banks knew how to mitigate banking distress and acted aggressively as a lender of last resort - propping up prices of assets on banks' balance sheet and restoring faith in the financial system (Richardson and Troost, 2009; Carlson, Mitchener, and Richardson, 2011). Furthermore, some Fed districts appear to have done been successful at convincing households and firms to keep their cash in banks (Richardson and Troost, 2009). Of course, why some Fed districts acted and others did 
not in 1930s is a political economy question that still resonates with policymakers (Bernanke, 2002). 


\section{References}

Adrian, Tobias, and Hyun Song Shin. (2010). "The Changing Nature of Financial Intermediation and Financial Crisis of 2007-2009.” Annual Review of Economics 2:603-618.

Allen, Franklin and Douglas Gale. (2000). "Financial Contagion" Journal of Political Economy 108:1-33.

Bernanke, Ben S. (1983). "Nonmonetary Effects of the Financial Crisis in the Propagation of the Great Depression.” American Economic Review 73(3): 257-276.

Bernanke, Ben S. (2002). "Remarks by Ben Bernanke: On Milton Friedman's 90 ${ }^{\text {th }}$ Birthday." University of Chicago, Chicago, Illinois, November 8.

Bernanke, Ben S. (2010). "Causes of the Recent Financial and Economic Crisis.” Statement before the Financial Crisis Inquiry Commission, Washington, DC, September 2. https://www. federalreserve.gov/newsevents/testimony/ bernanke20100902a.htm.

Bernanke, Ben S. (2013). The Federal Reserve and the Financial Crisis. Princeton: Princeton University Press.

Bernanke, Ben S. (2015). The Courage to Act: A Memoir of a Crisis and Its Aftermath. New York: Norton.

Board of Governors of the Federal Reserve System. (1943). Banking and Monetary Statistics 1914-1941. Federal Reserve Board: Washington, D.C.

Bordo, Michael D. (2003). "Comment on 'The Great Depression and the Friedman-Schwartz Hypothesis"” Journal of Money, Credit and Banking 35(6, Part 2): 1199-1203.

Calomiris, Charles and Gary Gorton. (1991). "The Origins of Banking Panics: Models, Facts, and Bank Regulation.” In Financial Markets and Financial Crises, edited by R. Glen Hubbard. Chicago: University of Chicago Press, pp. 109-174.

Calomiris, Charles W., and Joseph R. Mason (1997). “Contagion and Bank Failures During the Great Depression: The June 1932 Chicago Banking Panic." American Economic Review 87: 863-83.

Calomiris, Charles W., and Joseph R. Mason (2003a). "Fundamentals, Panics and Bank Distress During the Depression." (with Joseph Mason) American Economic Review 93: 1615-47.

Calomiris, Charles W., and Joseph R. Mason (2003b). “Consequences of Bank Distress During the Great Depression.” American Economic Review 93: 937-47. 
Cameron, A. Colin, Jonah B. Gelback, and Douglas L. Miller (2008). “Bootstrap-Based Improvements for Inference with Clustered Standard Errors.” The Review of Economics and Statistics, 90(3): 414-427

Cameron, Adrian Colin., and P. K. Trivedi. (2005) Microeconometrics: Methods and Applications. Cambridge: Cambridge University Press.

Carlson, Mark, Kris James Mitchener, and Gary Richardson. (2011). “Arresting Banking Panics: Federal Reserve Liquidity Provision and the Forgotten Panic of 1929." Journal of Political Economy 119(5): 889-924.

Cattaneo, Matias D, Michael Jansson, Xinwei Ma (2019). Two-Step Estimation and Inference with Possibly Many Included Covariates, The Review of Economic Studies, Volume 86, Issue 3, May 2019, Pages 1095-1122, https://doi.org/10.1093/restud/rdy053

Christiano, Lawrence J., Roberto Motto, Massimo Rostagno (2003).“"The Great Depression and the Friedman-Schwartz Hypothesis"" Journal of Money, Credit, and Banking, vol 35(6b), pages 1119-1197.

Chudik, Alexander, George Kapetanios, and M. Hashem Pesaran. "A One Covariate at a Time, Multiple Testing Approach to Variable Selection in High-Dimensional Linear Regression Models.” Econometrica 86.4 (2018): 1479-1512

Covitz, Daniel, Nellie Liang, and Gustavo A. Suarez. (2013). "Evolution of a Financial Crisis: Collapse of the Asset-Backed Commercial Paper Market.” Journal of Finance 68(3): 815-48.

Dasgupta, Amil. (2004). "Financial Contagion through Capital Connections: A Model of the Origin and Spread of Bank Panics." Journal of the European Economic Association 2(6): 1049-1084.

Davison, Lee K. and Ramirez, Carlos D. (2014). "Local Banking Panics of the 1920s: Identification and Determinants." Journal of Monetary Economics 66 (September): 164-177.

Diamond, Douglas W., and Philip H. Dybvig. (1983). "Bank Runs, Deposit Insurance, and Liquidity." Journal of Political Economy 91 (June): 401-19.

Douglas W. Diamond \& Raghuram G. Rajan (2006).“"Money in a Theory of Banking”" American Economic Review, American Economic Association, vol. 96(1), pages 3053, March.

Eichengreen, Barry. (2016). Hall of Mirrors. Oxford University Press. 
Eichengreen, Barry (1993). Golden Fetters: The Gold Standard and the Great Depression, 1919-1939. Oxford: Oxford University Press.

Federal Reserve Board of Governors. (1943). Banking and Monetary Statistics of the United States, 1914 to 1941. Board of Governors: Washington, D.C.

Federal Reserve Bank of New York. (1931). Seventeenth Annual Report for the Year Ending December 31, 1931. Federal Reserve Bank of New York: New York.

Feige, Edward. (1989). "Currency Velocity and cash payments in the U.S. Economy: The Currency Enigma.” MPRA Paper No. 13807. Online at http://mpra.ub.unimuenchen.de/13807/

Fisher, Irving. (1933). “The Debt-Deflation Theory of Great Depressions," Econometrica 1(4): 337-56.

Freixas, Xavier, Bruno Parigi, and Jean-Charles Rochet. (2000). "Systemic Risk, Interbank Relations, and Liquidity Provision by the Central Bank.” Journal of Money, Credit and Banking 32: 611-638.

Friedman, Milton, and Anna J. Schwartz. (1963). A Monetary History of the United States, 1867-1960. Princeton, NJ: Princeton University Press.

Gertler, Mark and Simon Gilchrist. (2018). "What Happened: Financial Factors in the Great Recession.” Journal of Economic Perspectives 32(3): 3-30

Gertler, Mark, Nobuhiro Kiyotaki, and Andrea Prestipino. (2017). “A Macroeconomic Model with Financial Panics.” NBER Working Paper 24126.

Gorton, Gary B. (2010). Slapped by the Invisible Hand: The Panic of 2007. New York: Oxford University Press.

Gorton, Gary B. and Andrew Metrick. (2012) "Securitized Banking and the Run on Repo," Journal of Financial Economics 104: 425-451.

Jalil, Andrew. (2015). “A New History of Banking Panics in the United States, 1825-1929: Construction and Implications." American Economic Journal: Macroeconomics. Jorda, Oscar, Moritz Schularick, and Alan M. Taylor. (2013). "When Credit Bites Back." Journal of Money, Credit and Banking, Supplement to 45(2): 3-27.

Kacperczyk, Marcin, and Philipp Schnabl. (2010). “When Safe Proved Risky: Commercial Paper During the Financial Crisis of 2007-2009.” Journal of Economic Perspectives 24(1): 29-50. 
Meltzer, A.H. (2003). A History of the Federal Reserve Volume 1, 1913-1951. Chicago:

University of Chicago Press.

Mishkin, Frederic S. (1978). "The Household Balance Sheet and the Great Depression." Journal of Economic History 38(4): 918-937.

Mishkin, Frederic S. and Eugene White (2014). "Unprecedented Actions: The Federal Reserve's Response to the Global Financial Crisis in Historical Perspective.” NBER Working Paper 20737 (December).

Mitchener, Kris James. (2007). “Are Supervision and Regulation Pillars of Financial Stability? Evidence from the Great Depression," Journal of Law and Economics vol. 50 (May): 273-302

Mitchener, Kris James and Gary Richardson. (2019). "Network Contagion and Interbank Amplification during the Great Depression.” Journal of Political Economy (April).

Park, Haelim and Gary Richardson (2012), "Retail Trade by Federal Reserve District, 1919 to 1939: A Statistical History." Research in Economic History (Volume 28). pp.151231.

Postel-Vinay, Natacha. (2016). "What Caused Chicago Bank Failures in the Great Depression? A Look at the 1920s.” Journal of Economic History. 76(2): 478-519. Rand McNally Bankers' Directory. (1929). Hanover National Bank: New York City. Reinhart, Carmen M., and Kenneth S. Rogoff. (2009). This Time Is Different: Eight Centuries of Financial Folly. Princeton, NJ: Princeton University Press. Richardson, Gary. (2007a). "Categories and Causes of Bank Distress during the Great Depression, 1929-1933: The Illiquidity-Insolvency Debate Revisited," Explorations in Economic History 44(4): 586-607.

Richardson, Gary. (2007b). "The Check is in the Mail: Correspondent Clearing and the Banking Panics of the Great Depression," Journal of Economic History 67(3): 643671.

Richardson, Gary. (2008). "Quarterly Data on the Categories and Causes of Bank Distress during the Great Depression," Research in Economic History 25 (January): 37-115. Richardson, Gary and William Troost. (2009). "Monetary Intervention Mitigated Banking Panics During the Great Depression: Quasi-Experimental Evidence from the Federal Reserve District Border in Mississippi, 1929 to 1933." Journal of Political Economy 117(6): 1031-1073. 
Romer, Christina D. (1993). “The Nation in Depression.” Journal of Economic Perspectives 7(2): 19-39.

Sims, Christopher. (2009). “Comment on Christiano, Motto and Rostagno (2009).” Mimeo. Princeton University (June 12, 2009).

Wicker, Elmus. (1996). The Banking Panics of the Great Depression. Cambridge: Cambridge University Press.

Wood, John. 2005. A History of Central Banking in Great Britain and the United States. New York: Cambridge Univ. Press.

Zellner, Arnold. (1962). “An Efficient Method of Estimating Seemingly Unrelated Regressions and Tests for Aggregation Bias.” Journal of the American Statistical Association 57, no.298 (June): 348- 368. 
Table 1: Bank Suspensions during Panics, March 1929-- December 1932

\begin{tabular}{|c|c|c|c|c|c|c|c|c|c|c|c|c|c|c|c|c|}
\hline \multirow[b]{2}{*}{ Year } & \multirow[b]{2}{*}{ Months } & \multicolumn{12}{|c|}{ Federal Reserve District } & \multicolumn{3}{|c|}{ Suspensions in U.S. } \\
\hline & & 1 & 2 & 3 & 4 & 5 & 6 & 7 & 8 & 9 & 10 & 11 & 12 & $\begin{array}{r}\text { Total } \\
\text { During } \\
\text { Panics }\end{array}$ & $\begin{array}{r}\% \text { of } \\
\text { All }\end{array}$ & $\begin{array}{r}\% \text { Fed } \\
\text { Member }\end{array}$ \\
\hline \multirow[t]{3}{*}{1929} & Apr - Jun & 0 & 0 & 0 & 2 & 0 & 15 & 0 & 0 & 2 & 0 & 0 & 0 & 19 & 17.0 & 26.3 \\
\hline & Jul - Sep & 0 & 0 & 0 & 0 & 2 & 19 & 2 & 0 & 3 & 2 & 0 & 0 & 28 & 22.6 & 7.1 \\
\hline & Oct - Dec & 0 & 0 & 1 & 0 & 2 & 0 & 14 & 0 & 0 & 14 & 0 & 0 & 31 & 19.9 & 16.1 \\
\hline \multirow[t]{4}{*}{1930} & Jan - Mar & 0 & 0 & 2 & 0 & 2 & 8 & 9 & 0 & 2 & 0 & 4 & 0 & 27 & 11.0 & 18.5 \\
\hline & Apr - Jun & 0 & 0 & 0 & 0 & 9 & 15 & 7 & 7 & 2 & 7 & 0 & 0 & 47 & 21.0 & 12.8 \\
\hline & Jul - Sep & 0 & 0 & 0 & 4 & 2 & 2 & 29 & 2 & 0 & 8 & 0 & 0 & 47 & 24.0 & 10.6 \\
\hline & Oct $-\mathrm{Dec}$ & 2 & 2 & 4 & 0 & 30 & 13 & 37 & 118 & 16 & 5 & 5 & 2 & 234 & 34.7 & 17.5 \\
\hline \multirow[t]{4}{*}{1931} & Jan - Mar & 0 & 2 & 7 & 2 & 4 & 11 & 37 & 23 & 3 & 6 & 0 & 2 & 97 & 25.9 & 14.4 \\
\hline & Apr - Jun & 0 & 2 & 6 & 8 & 6 & 0 & 75 & 0 & 9 & 0 & 0 & 0 & 106 & 31.5 & 25.5 \\
\hline & Jul - Sep & 1 & 10 & 5 & 28 & 4 & 5 & 72 & 6 & 25 & 15 & 3 & 2 & 176 & 33.6 & 22.2 \\
\hline & Oct - Dec & 21 & 24 & 40 & 34 & 55 & 3 & 98 & 52 & 15 & 31 & 11 & 10 & 394 & 37.8 & 24.1 \\
\hline \multirow[t]{3}{*}{1932} & Jan - Jun & 4 & 0 & 4 & 4 & 2 & 5 & 120 & 33 & 3 & 19 & 2 & 32 & 228 & 27.6 & 25.9 \\
\hline & Jul - Sep & 0 & 0 & 0 & 2 & 4 & 2 & 25 & 2 & 4 & 4 & 0 & 5 & 48 & 16.9 & 27.1 \\
\hline & Oct - Dec & 0 & 0 & 0 & 3 & 0 & 7 & 31 & 2 & 2 & 6 & 0 & 8 & 59 & 16.7 & 23.7 \\
\hline \multirow{3}{*}{\multicolumn{2}{|c|}{$\begin{array}{l}\text { Total During Panics } \\
\% \text { of All } \\
\% \text { Fed Member }\end{array}$}} & 28 & 40 & 69 & 87 & 122 & 105 & 556 & 245 & 86 & 117 & 25 & 61 & 1,541 & & \\
\hline & & 50.9 & 39.2 & 48.9 & 30.3 & 26.6 & 23.6 & 37.0 & 30.7 & 14.0 & 18.1 & 14.5 & 24.1 & 28.2 & & \\
\hline & & 21.4 & 57.5 & 17.4 & 36.8 & 28.7 & 21.0 & 18.3 & 16.7 & 17.4 & 9.4 & 44.0 & 32.8 & 21.4 & & \\
\hline
\end{tabular}

Note: Table reports bank suspensions occurring during panics in each Federal Reserve District where panics are defined as suspensions occurring within a 10-mile radius, no more than 30 days apart, and statistically different from being spatially random ("10-30 joins" as described in the text). \% of all is share of panic suspensions relative to all suspensions for a given time period or district. \% Fed member indicates share of panic suspensions that were Fed members. 
Table 2. Bank Suspensions and Demand Deposit Flows at Member Banks, June 1929-December 1932

\begin{tabular}{|c|c|c|c|c|c|c|c|}
\hline \multirow[b]{2}{*}{ Independent Variables } & \multicolumn{7}{|c|}{ Estimation Method and Panic Period Definition } \\
\hline & OLS & Panel FE & Panel FE & $\begin{array}{l}\text { Panel FE \& } \\
\text { 10-30 Joins }\end{array}$ & $\begin{array}{c}\text { Panel FE \& } \\
\text { 4-10-30 Clusters }\end{array}$ & $\begin{array}{l}\text { Panel FE \& } \\
\text { 10-30 Joins } \\
\end{array}$ & $\begin{array}{c}\text { Panel FE \& } \\
\text { 4-10-30 Clusters }\end{array}$ \\
\hline Bank Suspensions & $\begin{array}{c}-165,672 * * * \\
(52,832)\end{array}$ & $\begin{array}{l}-63,749^{*} \\
(33,278)\end{array}$ & $\begin{array}{l}-40,318 \\
(38,140)\end{array}$ & & & & \\
\hline Bank Suspensions $*$ Reserve City & $\begin{array}{c}25,609 \\
(66,542)\end{array}$ & $\begin{array}{l}-60,631 \\
(56,933)\end{array}$ & $\begin{array}{l}-59,277 \\
(59,292)\end{array}$ & & & & \\
\hline Bank Suspensions * Chicago & $\begin{array}{c}73,927 \\
(63,145)\end{array}$ & $\begin{array}{c}-157,438 * * * \\
(32,005)\end{array}$ & $\begin{array}{c}-168,174 * * * \\
(32,784)\end{array}$ & & & & \\
\hline Panic-Period Bank Suspensions & & & & $\begin{array}{c}-694,029 * * * \\
(169,547)\end{array}$ & $\begin{array}{l}-586,151 * \\
(309,329)\end{array}$ & $\begin{array}{c}-692,563 * * * \\
(201,675)\end{array}$ & $\begin{array}{l}-533,173 * \\
(286,028)\end{array}$ \\
\hline Panic-Period Bank Suspensions $*$ Reserve City & & & & $\begin{array}{l}389,790 * \\
(198,602)\end{array}$ & $\begin{array}{c}-74,957 \\
(310,384)\end{array}$ & $\begin{array}{c}390,652 * * \\
(170,809)\end{array}$ & $\begin{array}{c}-74,577 \\
(306,430)\end{array}$ \\
\hline Panic-Period Suspensions $*$ Chicago & & & & $\begin{array}{l}-161,342 \\
(173,938)\end{array}$ & $\begin{array}{l}-384,314 \\
(310,459)\end{array}$ & $\begin{array}{l}-147,023 \\
(182,118)\end{array}$ & $\begin{array}{l}-424,740 \\
(277,304)\end{array}$ \\
\hline Non-Panic-Period Suspensions & & & & $\begin{array}{r}491,796 * * \\
(184,456)\end{array}$ & $\begin{array}{c}138,598 \\
(109,501)\end{array}$ & $\begin{array}{r}578,727 * * \\
(234,616)\end{array}$ & $\begin{array}{c}176,739 \\
(108,603)\end{array}$ \\
\hline Non-Panic-Period $*$ Reserve City & & & & $\begin{array}{c}-395,350 * * \\
(189,001)\end{array}$ & $\begin{array}{l}-55,216 \\
(100,083)\end{array}$ & $\begin{array}{c}-397,019 * * \\
(167,529)\end{array}$ & $\begin{array}{c}-56,079 \\
(105,711)\end{array}$ \\
\hline Non-Panic-Period Suspensions $*$ Chicago & & & & $\begin{array}{l}-299,461 * \\
(170,536)\end{array}$ & $\begin{array}{c}-162,423 \\
(99,879)\end{array}$ & $\begin{array}{l}-342,457 * \\
(193,675)\end{array}$ & $\begin{array}{l}-180,013 \\
(110,275)\end{array}$ \\
\hline Observations & 350 & 350 & 350 & 350 & 350 & 350 & 350 \\
\hline R-squared & 0.048 & 0.365 & 0.465 & 0.486 & 0.480 & 0.560 & 0.553 \\
\hline Neighbor-Time Effects & No & No & No & No & No & Yes & Yes \\
\hline District Time Varying Controls & No & Yes & Yes & Yes & Yes & Yes & Yes \\
\hline Time Fixed Effects & No & No & Yes & Yes & Yes & Yes & Yes \\
\hline Time Trend & No & Yes & No & No & No & No & No \\
\hline SE Robust \& Clustered & No & Yes & Yes & Yes & Yes & Yes & Yes \\
\hline
\end{tabular}

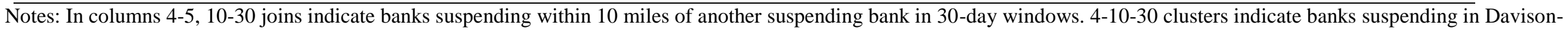
Ramirez clusters with parameters 10 days, 30 miles, and 4 banks, as described in text. Non-panic suspensions are all suspensions minus panic suspensions. Standard errors in parentheses calculated using Huber-White method and are clustered on Federal Reserve districts and central reserve cities. $* * *$ indicates $\mathrm{p}<0.01, * * \mathrm{p}<0.05, * \mathrm{p}<0.1$. 
Table 3. Bank Suspensions and Time Deposit Flows at Member Banks, June 1929-December 1932

\begin{tabular}{|c|c|c|c|c|c|c|c|}
\hline \multirow[b]{2}{*}{ Independent Variables } & \multicolumn{7}{|c|}{ Estimation Method and Panic Period Definition } \\
\hline & OLS & Panel FE & Panel FE & $\begin{array}{l}\text { Panel FE \& } \\
\text { 10-30 Joins }\end{array}$ & $\begin{array}{c}\text { Panel FE \& } \\
\text { 4-10-30 Clusters }\end{array}$ & $\begin{array}{l}\text { Panel FE \& } \\
\text { 10-30 Joins }\end{array}$ & $\begin{array}{c}\text { Panel FE \& } \\
\text { 4-10-30 Clusters }\end{array}$ \\
\hline All Suspensions & $\begin{array}{c}-310,412 * * * \\
(42,731)\end{array}$ & $\begin{array}{c}-210,621 * * * \\
(64,753)\end{array}$ & $\begin{array}{c}-175,869 * * \\
(76,851)\end{array}$ & & & & \\
\hline All Suspensions * Reserve City & $\begin{array}{l}93,049 * \\
(53,820)\end{array}$ & $\begin{array}{c}17,454 \\
(93,257)\end{array}$ & $\begin{array}{c}17,450 \\
(95,250)\end{array}$ & & & & \\
\hline All Suspensions * Chicago & $\begin{array}{c}217,319 * * * \\
(51,072)\end{array}$ & $\begin{array}{c}53,252 \\
(64,270)\end{array}$ & $\begin{array}{c}34,932 \\
(71,466)\end{array}$ & & & & \\
\hline Panic Suspensions & & & & $\begin{array}{c}-745,689 * * * \\
(144,874)\end{array}$ & $\begin{array}{c}-1.056 \mathrm{e}+06 * * * \\
(266,393)\end{array}$ & $\begin{array}{c}-772,003 * * * \\
(222,489)\end{array}$ & $\begin{array}{c}-1.314 \mathrm{e}+06 * * * \\
(356,336)\end{array}$ \\
\hline Panic Suspensions * Reserve City & & & & $\begin{array}{c}46,451 \\
(245,145)\end{array}$ & $\begin{array}{c}252,824 \\
(461,864)\end{array}$ & $\begin{array}{c}47,911 \\
(271,468)\end{array}$ & $\begin{array}{c}253,502 \\
(462,733)\end{array}$ \\
\hline Panic Suspensions $*$ Chicago & & & & $\begin{array}{c}458,125 * * * \\
(161,051)\end{array}$ & $\begin{array}{c}904,511 * * * \\
(271,315)\end{array}$ & $\begin{array}{c}473,137 * * \\
(186,594)\end{array}$ & $\begin{array}{c}878,499 * * * \\
(300,719)\end{array}$ \\
\hline Other Suspensions & & & & $\begin{array}{l}306,696^{*} \\
(153,765)\end{array}$ & $\begin{array}{c}101,073 \\
(130,483)\end{array}$ & $\begin{array}{c}342,485 \\
(241,224)\end{array}$ & $\begin{array}{c}188,811 \\
(202,530)\end{array}$ \\
\hline Other Suspensions * Reserve City & & & & $\begin{array}{c}-4,824 \\
(216,245)\end{array}$ & $\begin{array}{c}-47,507 \\
(160,259)\end{array}$ & $\begin{array}{c}-7,651 \\
(246,147)\end{array}$ & $\begin{array}{c}-49,048 \\
(193,221)\end{array}$ \\
\hline Other Suspensions $*$ Chicago & & & & $\begin{array}{c}-335,964 * * \\
(138,605)\end{array}$ & $\begin{array}{l}-227,001 * \\
(114,729)\end{array}$ & $\begin{array}{l}-380,894 * \\
(211,704)\end{array}$ & $\begin{array}{l}-280,243 \\
(180,826)\end{array}$ \\
\hline Observations & 350 & 350 & 350 & 350 & 350 & 350 & 350 \\
\hline R-squared & 0.168 & 0.309 & 0.326 & 0.352 & 0.351 & 0.517 & 0.526 \\
\hline Neighbor-Time Effects & No & No & No & No & No & Yes & Yes \\
\hline District Time Varying Controls & No & Yes & Yes & Yes & Yes & Yes & Yes \\
\hline Time Fixed Effects & No & No & Yes & Yes & Yes & Yes & Yes \\
\hline Time Trend & No & Yes & No & No & No & No & No \\
\hline SE Robust \& Clustered & No & Yes & Yes & Yes & Yes & Yes & Yes \\
\hline
\end{tabular}

Notes: In columns 4 to 7, 10-30 joins indicate banks suspending within 10 miles of another suspending bank in 30-day windows. 4-10-30 clusters indicate banks suspending in Davison-Ramirez clusters with parameters 10 days, 30 miles, and 4 banks, as described in text. Non-panic suspensions are all suspensions minus panic suspensions. District timevarying controls include changes in discount rates, consumption, and building permits. Standard errors in parentheses calculated using Huber-White method and are clustered on Federal Reserve districts and central reserve cities. $* * *$ indicates $\mathrm{p}<0.01, * * \mathrm{p}<0.05, * \mathrm{p}<0.1$. 
Table 4. Bank Suspensions and Public Deposit Flows at Nonmember Banks, June 1929-December 1932

\begin{tabular}{|c|c|c|c|c|c|c|c|}
\hline \multirow[b]{2}{*}{ Independent Variables } & \multicolumn{7}{|c|}{ Estimation Method and Panic Period Definition } \\
\hline & OLS & Panel FE & Panel FE & $\begin{array}{l}\text { Panel FE \& } \\
\text { 10-30 Joins }\end{array}$ & $\begin{array}{c}\text { Panel FE \& } \\
\text { 4-10-30 Clusters }\end{array}$ & $\begin{array}{l}\text { Panel FE \& } \\
\text { 10-30 Joins }\end{array}$ & $\begin{array}{c}\text { Panel FE \& } \\
\text { 4-10-30 Clusters }\end{array}$ \\
\hline All Suspensions & $\begin{array}{c}-901,892 * * * \\
(165,699)\end{array}$ & $\begin{array}{c}-909,088 * * \\
(405,922)\end{array}$ & $\begin{array}{l}-703,743 \\
(497,362)\end{array}$ & & & & \\
\hline Panic Suspensions & & & & $\begin{array}{c}-2.767 \mathrm{e}+06^{* * *} \\
(1.022 \mathrm{e}+06)\end{array}$ & $\begin{array}{c}-7.540 \mathrm{e}+06 * * * \\
(1.296 \mathrm{e}+06)\end{array}$ & $\begin{array}{c}-2.114 \mathrm{e}+06 \\
(1.245 \mathrm{e}+06)\end{array}$ & $\begin{array}{c}-6.675 \mathrm{e}+06 * * * \\
(1.329 \mathrm{e}+06)\end{array}$ \\
\hline Other Suspensions & & & & $\begin{array}{c}1.055 \mathrm{e}+06^{* *} * \\
(340,299)\end{array}$ & $\begin{array}{c}1.497 \mathrm{e}+06^{* * *} \\
(370,074)\end{array}$ & $\begin{array}{c}552,734 \\
(518,310)\end{array}$ & $\begin{array}{c}1.260 \mathrm{e}+06^{* *} \\
(484,692)\end{array}$ \\
\hline Observations & 156 & 156 & 156 & 156 & 156 & 156 & 156 \\
\hline R-squared & 0.161 & 0.197 & 0.265 & 0.299 & 0.451 & 0.558 & 0.655 \\
\hline Neighbor-Time Effects & No & No & No & No & No & Yes & Yes \\
\hline District Time Varying Controls & No & Yes & Yes & Yes & Yes & Yes & Yes \\
\hline Time Fixed Effects & No & No & Yes & Yes & Yes & Yes & Yes \\
\hline Time Trend & No & Yes & No & No & No & No & No \\
\hline SE Robust \& Clustered & No & Yes & Yes & Yes & Yes & Yes & Yes \\
\hline
\end{tabular}

Notes: In columns 4 to 7, 10-30 joins indicate banks suspending within 10 miles of another suspending bank in 30-day windows. 4-10-30 clusters indicate banks suspending in Davison-Ramirez clusters with parameters 10 days, 30 miles, and 4 banks, as described in text. Non-panic suspensions are all suspensions minus panic suspensions. District time-varying controls include changes in discount rates, consumption, and building permits. Standard errors in parentheses calculated using Huber-White method and are clustered on Federal Reserve districts and central reserve cities. *** indicates $\mathrm{p}<0.01, * * \mathrm{p}<0.05, * \mathrm{p}<0.1$. 
Table 5. Public Deposit Flows and Asset Allocations, June 1929- December 1932

Panel A. Member Banks

\begin{tabular}{lccccc}
\hline & \multicolumn{5}{c}{ Asset Category } \\
& Loans & $\begin{array}{c}\text { Government } \\
\text { Bonds }\end{array}$ & $\begin{array}{c}\text { Corporate } \\
\text { Bonds }\end{array}$ & $\begin{array}{c}\text { Cash and } \\
\text { Reserves }\end{array}$ & $\begin{array}{c}\text { Interbank } \\
\text { Balances }\end{array}$ \\
\hline Inflows & & & & & \\
Member Country Banks & 0.2216 & 0.0057 & $0.1779 * * *$ & $0.3666^{* * *}$ & -0.0539 \\
& $(0.1788)$ & $(0.2905)$ & $(0.0626)$ & $(0.0814)$ & $(0.0835)$ \\
Member Reserve City Banks & $0.3385^{* * *}$ & -0.1193 & $0.1637 * * *$ & $0.3274 * * *$ & $0.1196 * * *$ \\
& $(0.0719)$ & $(0.1169)$ & $(0.0252)$ & $(0.0328)$ & $(0.0336)$ \\
Outflows & & & & & \\
Member Country Banks & $0.5386^{* * *}$ & 0.0355 & $0.1383^{* * *}$ & $0.1312^{* * *}$ & $0.1419 * * *$ \\
& $(0.0869)$ & $(0.1413)$ & $(0.0305)$ & $(0.0396)$ & $(0.0406)$ \\
Member Reserve City Banks & $0.3499^{* * *}$ & 0.0777 & $0.0522^{* *}$ & $0.4192^{* * *}$ & $0.1478^{* * *}$ \\
& $(0.0705)$ & $(0.1145)$ & $(0.0247)$ & $(0.0321)$ & $(0.0329)$ \\
Observations & 322 & 322 & 322 & 322 & 322 \\
R-squared & 0.417 & 0.072 & 0.427 & 0.622 & 0.551 \\
\hline
\end{tabular}

Panel B. Non-Member Banks

\begin{tabular}{lcc}
\hline & \multicolumn{2}{c}{ Asset Category } \\
& Loans & Investments \\
\hline Public deposits inflows & -0.0325 & $0.352 * * *$ \\
All Nonmember Banks & $(0.0697)$ & $(0.0526)$ \\
& & \\
Public deposits outflows & $0.508 * * *$ & $0.223 * * *$ \\
All Nonmember Banks & $(0.0404)$ & $(0.0305)$ \\
& & \\
Observations & 156 & 156 \\
R-squared & 0.506 & 0.425 \\
\hline
\end{tabular}

Notes: Table based upon estimation of Equation (2) as described in the text. Standard errors indicated in parentheses below estimated magnitudes. P-values indicated with asterisks: $* \mathrm{p}<0.10$; ** $\mathrm{p}<$ $0.05 ; * * * \mathrm{p}<0.01$. Public deposits are the sum of time and demand deposits. 
Table 6. Time and Demand Deposit Flows and Asset Allocations in Member Banks, June 1929- December 1932

\begin{tabular}{|c|c|c|c|c|c|}
\hline & \multicolumn{5}{|c|}{ Asset Category } \\
\hline & Loans & $\begin{array}{c}\text { Government } \\
\text { Bonds }\end{array}$ & $\begin{array}{c}\text { Corporate } \\
\text { Bonds }\end{array}$ & $\begin{array}{l}\text { Cash and } \\
\text { Reserves }\end{array}$ & $\begin{array}{c}\text { Interbank } \\
\text { Balances }\end{array}$ \\
\hline \multicolumn{6}{|c|}{ Demand deposits inflows } \\
\hline Country banks & $\begin{array}{l}0.1008 \\
(0.208)\end{array}$ & $\begin{array}{c}-0.0241 \\
(0.3478)\end{array}$ & $\begin{array}{c}0.2167 * * * \\
(0.0722)\end{array}$ & $\begin{array}{c}0.2899 * * * \\
(0.0848)\end{array}$ & $\begin{array}{c}0.0752 \\
(0.0984)\end{array}$ \\
\hline Reserve Cities & $\begin{array}{l}-0.2087 \\
(0.1803)\end{array}$ & $\begin{array}{l}-0.1315 \\
(0.3014)\end{array}$ & $\begin{array}{c}0.1401 * * \\
(0.0626)\end{array}$ & $\begin{array}{c}0.4882 * * * \\
(0.0735)\end{array}$ & $\begin{array}{c}0.0764 \\
(0.0852)\end{array}$ \\
\hline \multicolumn{6}{|c|}{ Demand deposits outflows } \\
\hline Country banks & $\begin{array}{c}0.3875 * * * \\
(0.1432)\end{array}$ & $\begin{array}{c}0.0229 \\
(0.2394)\end{array}$ & $\begin{array}{c}-0.0384 \\
(0.0497)\end{array}$ & $\begin{array}{c}0.3493 * * * \\
(0.0584)\end{array}$ & $\begin{array}{c}0.0007 \\
(0.0677)\end{array}$ \\
\hline Reserve Cities & $\begin{array}{c}0.359 * * * \\
(0.0918)\end{array}$ & $\begin{array}{c}-0.0151 \\
(0.1535)\end{array}$ & $\begin{array}{c}0.0279 \\
(0.0319)\end{array}$ & $\begin{array}{c}0.6153 * * * \\
(0.0374)\end{array}$ & $\begin{array}{c}0.2087 * * * \\
(0.0434)\end{array}$ \\
\hline \multicolumn{6}{|c|}{ Time deposits inflows } \\
\hline Country banks & $\begin{array}{c}0.5484 \\
(0.5599)\end{array}$ & $\begin{array}{c}0.1475 \\
(0.9362)\end{array}$ & $\begin{array}{c}0.2703 \\
(0.1944)\end{array}$ & $\begin{array}{c}0.1904 \\
(0.2284)\end{array}$ & $\begin{array}{l}-0.4094 \\
(0.2647)\end{array}$ \\
\hline Reserve Cities & $\begin{array}{c}0.5879 * * * \\
(0.124)\end{array}$ & $\begin{array}{c}-0.106 \\
(0.2073)\end{array}$ & $\begin{array}{c}0.1993 * * * \\
(0.043)\end{array}$ & $\begin{array}{c}0.205 * * * \\
(0.0506)\end{array}$ & $\begin{array}{c}0.1269 * * \\
(0.0586)\end{array}$ \\
\hline \multicolumn{6}{|c|}{ Time deposits outflows } \\
\hline Country banks & $\begin{array}{c}0.7649 * * * \\
(0.1431)\end{array}$ & $\begin{array}{c}0.0533 \\
(0.2393)\end{array}$ & $\begin{array}{c}0.3065 * * * \\
(0.0497)\end{array}$ & $\begin{array}{c}-0.0699 \\
(0.0584)\end{array}$ & $\begin{array}{c}0.2804 * * * \\
(0.0677)\end{array}$ \\
\hline Reserve Cities & $\begin{array}{c}0.5945^{* * *} * \\
(0.1494)\end{array}$ & $\begin{array}{c}0.2408 \\
(0.2498)\end{array}$ & $\begin{array}{l}0.0858^{*} \\
(0.0519)\end{array}$ & $\begin{array}{c}0.0015 \\
(0.0609)\end{array}$ & $\begin{array}{c}0.0575 \\
(0.0706)\end{array}$ \\
\hline Observations & 322 & 322 & 322 & 322 & 322 \\
\hline R-squared & 0.450 & 0.073 & 0.469 & 0.714 & 0.566 \\
\hline
\end{tabular}

Notes: Table based upon estimation of equation (2) from the text. Standard errors are indicated in parentheses. P-values indicated with asterisks: $* \mathrm{p}<0.10 ; * * \mathrm{p}<0.05 ; * * * \mathrm{p}<0.01$ 
Table 7: Aggregate Impact of Panics on Commercial Bank Lending and Investments, June 1929 to December 1932

Definition of Panic-Period Suspensions and Estimation Method

\begin{tabular}{cccccccc} 
All & All & All & 10-30 Joins & 4-10-30 Clusters & 10-30 Joins & 4-10-30 Clusters & BMA \\
OLS & Panel FE & Panel FE & Panel FE & Panel FE & Panel FE Regions & Panel FE Regions & \\
\hline
\end{tabular}

Change by banks outside NY City ...

\section{$-3,516$ \\ $-2,871$}

$-3,608$

$-7,124$

- All banks (\$mil)

- All banks (standard error)

- All banks (\% of total decline in bank lending)

$(3,127)$

$-44.8$

$-3,637$

$-6,509$

$(3,941)$

$-2,397$

$-2,816$

$-5,212$

$-40.9$

$(4,243)$

$-32.7$

$-372.9$

$-340.7$

2.1

$-272.8$

- All banks (\$mil)

2.3
$-2,919$

$-3,117$

$-6,036$

$(2,423)$

$-37.9$

$-315.9$

2.0
$-1,698$

$-3,919$

$-5,617$

$(2,184)$

$-35.3$

$-294.0$

1.8
$-2,987$

$-2,381$

$-5,368$

(3,020)

$-33.7$

$-281.0$

1.8
$-2,062 \quad-3,102$

$-3,469 \quad-3,344$

$-5,531 \quad-6,446$

$(2,662)$

$\begin{array}{ll}-34.8 & 40.5\end{array}$

$-289.5 \quad-337.4$

$\begin{array}{ll}1.8 & 2.1\end{array}$

Notes: Standard errors are bootstrapped. See the text for details on calculations. Lending for member banks includes both loans and corporate bonds.

Lending for non-members includes loans, corporate bonds, and government bonds. Alternative assumptions for 1933 described in text. FE indicates fixed effects estimation method. 
Table 8: Effects of Banking Panics on Monetary Aggregates, June 1929 to December 1932

\begin{tabular}{|c|c|c|c|c|c|c|}
\hline & \multicolumn{2}{|c|}{$\begin{array}{c}\text { Change in } \\
\text { Money Multiplier }\end{array}$} & \multicolumn{4}{|c|}{$\begin{array}{c}\text { Change in Money Supply } \\
\text { (\$ Million) }\end{array}$} \\
\hline & Observed & $\begin{array}{l}\text { Due to } \\
\text { Panics }\end{array}$ & Observed & $\begin{array}{l}\text { Due to } \\
\text { Panics }\end{array}$ & $\begin{array}{r}\text { Due to } \\
\text { Monetary } \\
\text { Base }\end{array}$ & $\begin{array}{r}\text { Due to } \\
\text { Other Factors } \\
\text { and } \\
\text { Interaction } \\
\end{array}$ \\
\hline Oct-29 & -0.0002 & -0.0238 & 569 & -168 & 1,155 & -418 \\
\hline Dec-29 & -0.0167 & -0.0117 & -470 & -84 & 243 & -629 \\
\hline Mar-30 & 0.0961 & -0.0274 & $-1,244$ & -199 & $-2,427$ & 1,382 \\
\hline Jun-30 & 0.1721 & -0.0426 & 494 & -293 & 451 & 336 \\
\hline Sep-30 & -0.2587 & -0.0730 & -715 & -508 & -347 & 140 \\
\hline Dec-30 & -0.4452 & -0.1340 & -498 & -925 & 3,137 & $-2,710$ \\
\hline Mar-31 & 0.2268 & -0.0889 & $-1,163$ & -656 & $-2,722$ & 2,215 \\
\hline Jun-31 & -0.2545 & -0.6073 & -389 & $-4,210$ & 1,925 & 1,896 \\
\hline Sep-31 & -0.6876 & -0.3896 & $-1,400$ & $-2,820$ & 2,313 & -893 \\
\hline Dec-31 & -0.8270 & -0.6127 & $-2,611$ & $-4,672$ & 3,577 & $-1,516$ \\
\hline Jun-32 & -0.1156 & -0.1592 & $-3,960$ & $-1,318$ & $-2,786$ & 143 \\
\hline Sep-32 & -0.1824 & -0.0786 & -439 & -604 & 939 & -773 \\
\hline Dec-32 & -0.2414 & -0.0710 & 321 & -560 & 1,374 & -493 \\
\hline $\begin{array}{l}\text { Total Change: June 1929- } \\
\text { December } 1932\end{array}$ & -2.5341 & -2.3198 & $-11,505$ & $-17,018$ & 6,832 & $-1,319$ \\
\hline $\begin{array}{l}\text { Share of total observed } \\
\text { change }\end{array}$ & & $91.5 \%$ & & $147.9 \%$ & $-59.4 \%$ & $11.5 \%$ \\
\hline $\begin{array}{l}\text { Percent Relative to June } \\
1929\end{array}$ & & & & $-36.4 \%$ & $14.6 \%$ & $-2.8 \%$ \\
\hline
\end{tabular}

Notes: Column 1 indicates the month and year at the end of a call-report interval (i.e. date $t$ ). Columns 2 and 4 report observed changes from t- 1 to $t$ in our data on monetary aggregates at the call-report frequency. Columns 3 and 5 indicate our estimate of how panics impacted monetary aggregates (based on equations 5 and 6). Column 6 equals column 3 minus columns 4 and 5. Shares of total observed change for the money multiplier are slightly overestimated due to compounding. 
Figure 1. Bank Suspensions during the Caldwell Panic

\section{Regional Shocks During Depression - Initial Banking Crisis}

- Week of November 16, 1930: Caldwell Closes

November 24, 1930 to January 17, 1931: Caldwell and Bank of U.S. Aftershock

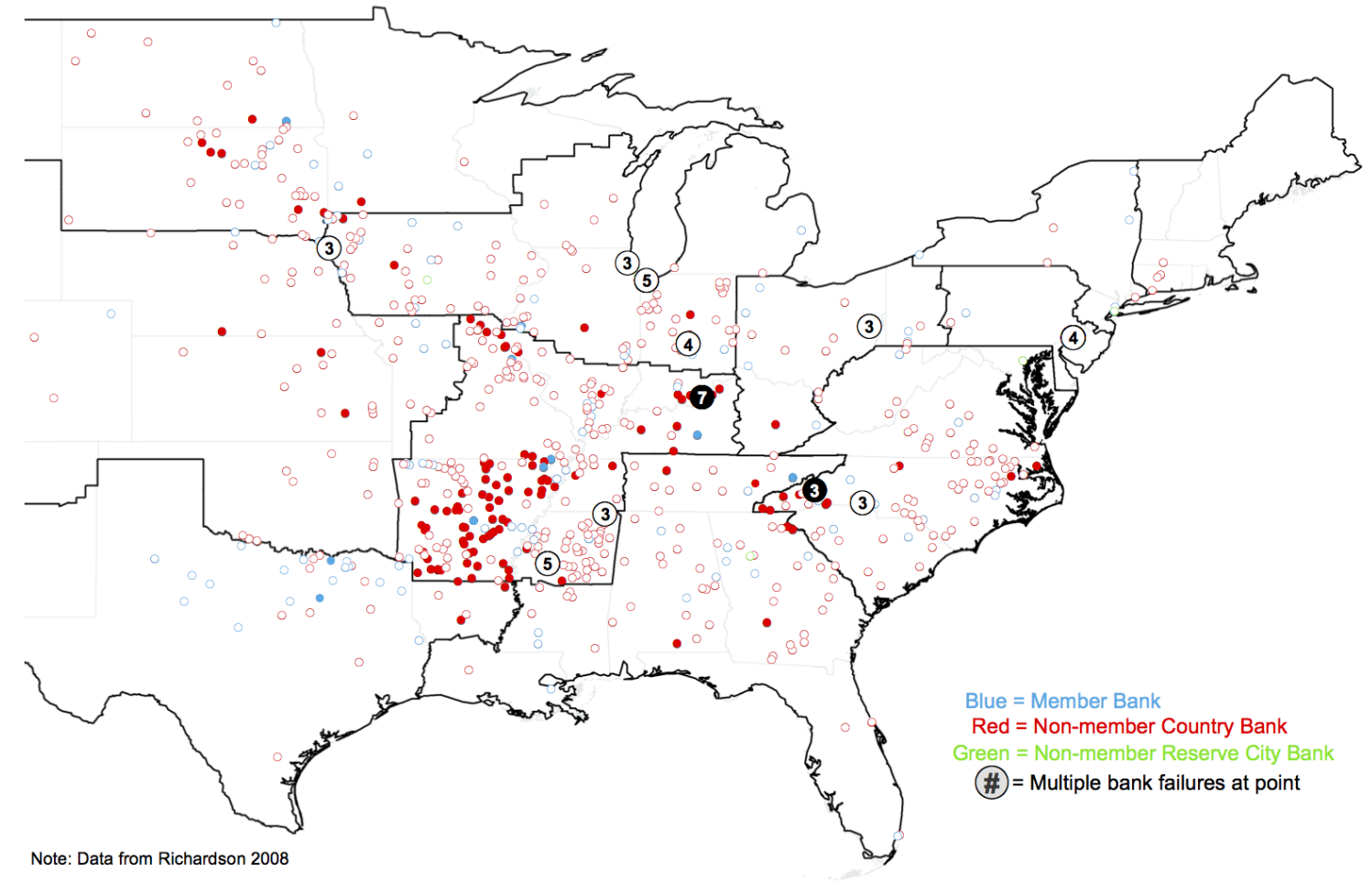


Figure 2. U.S. Bank Suspensions after Britain's departure from the Gold Standard

National Shock During Depression - Fall 1931

- September 21 to October 8, 1931: Crisis After Britain Goes Off Gold

October 9 to November 7, 1931: Aftershock of Discount Rate Increases



Blue $=$ Member Bank

Red $=$ Non-member Country Bank

\#) = Multiple bank failures at point

Note: Data from Richardson 2008 
Figure 3. Banking Panics and the Decline in Demand Deposits in 100 Cities

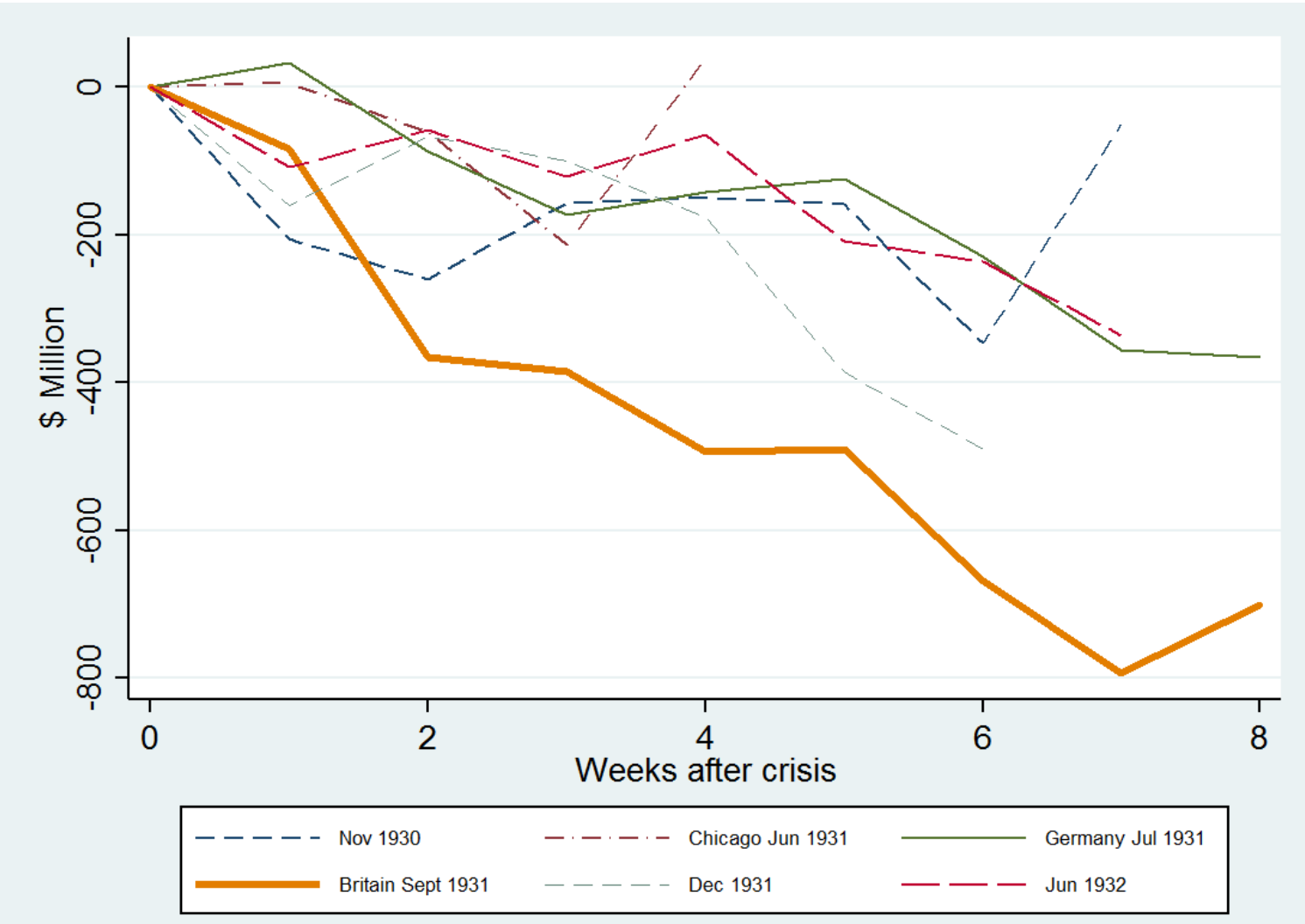

Notes: Deposit figures are reported for banks in Chicago, all reserve cities, and roughly forty other cities. Panic definitions are described in the text. 


\section{Figure 4. Banking Panics and the Decline in Time Deposits in 100 Cities}

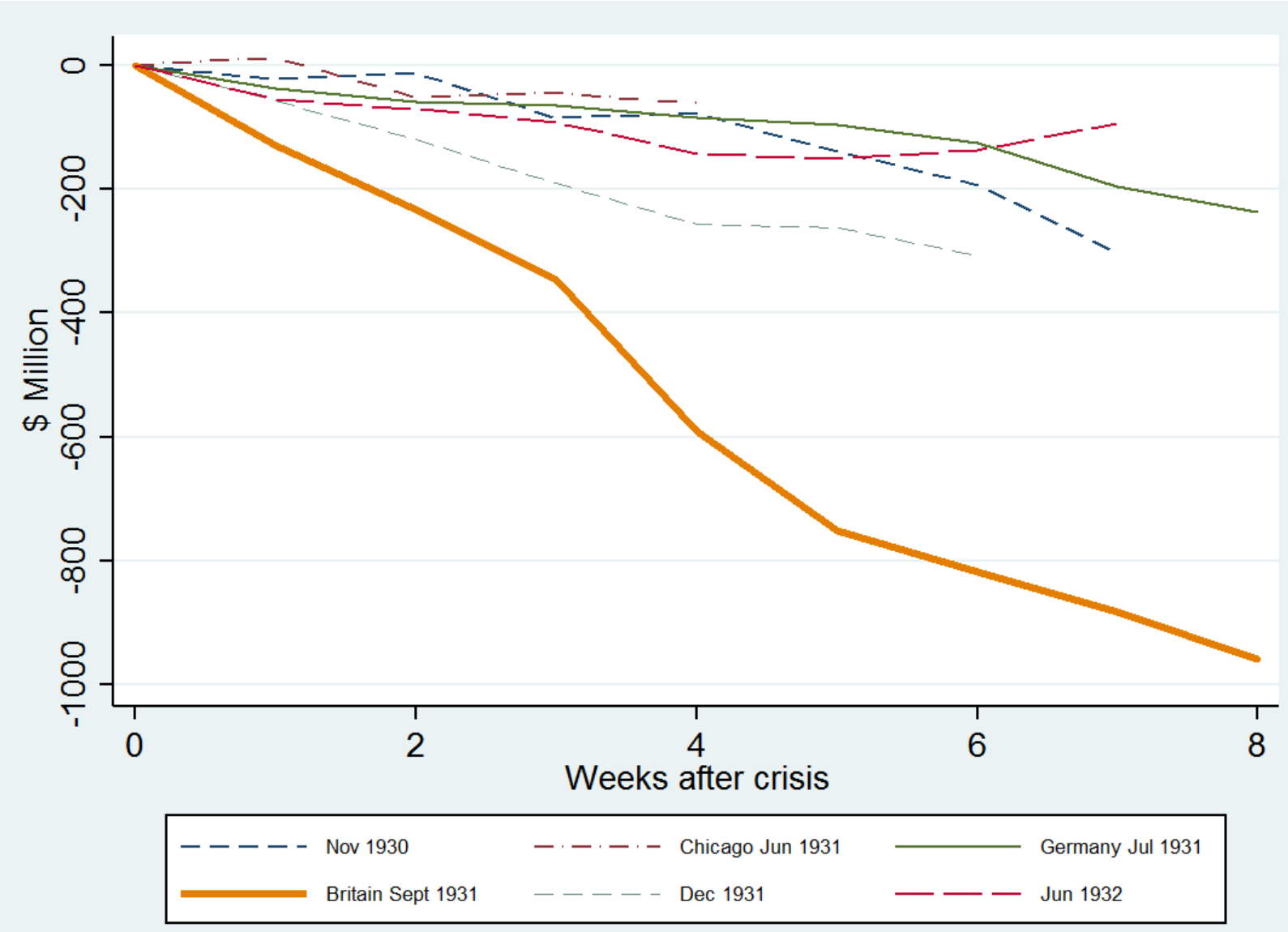

Notes: Deposit figures are reported for banks in Chicago, all reserve cities, and roughly forty other cities as described in the text. Panic definitions are described in the text. 
Figure 5. Banking Panics and Changes in Demand Deposits in Reporting New York City Banks

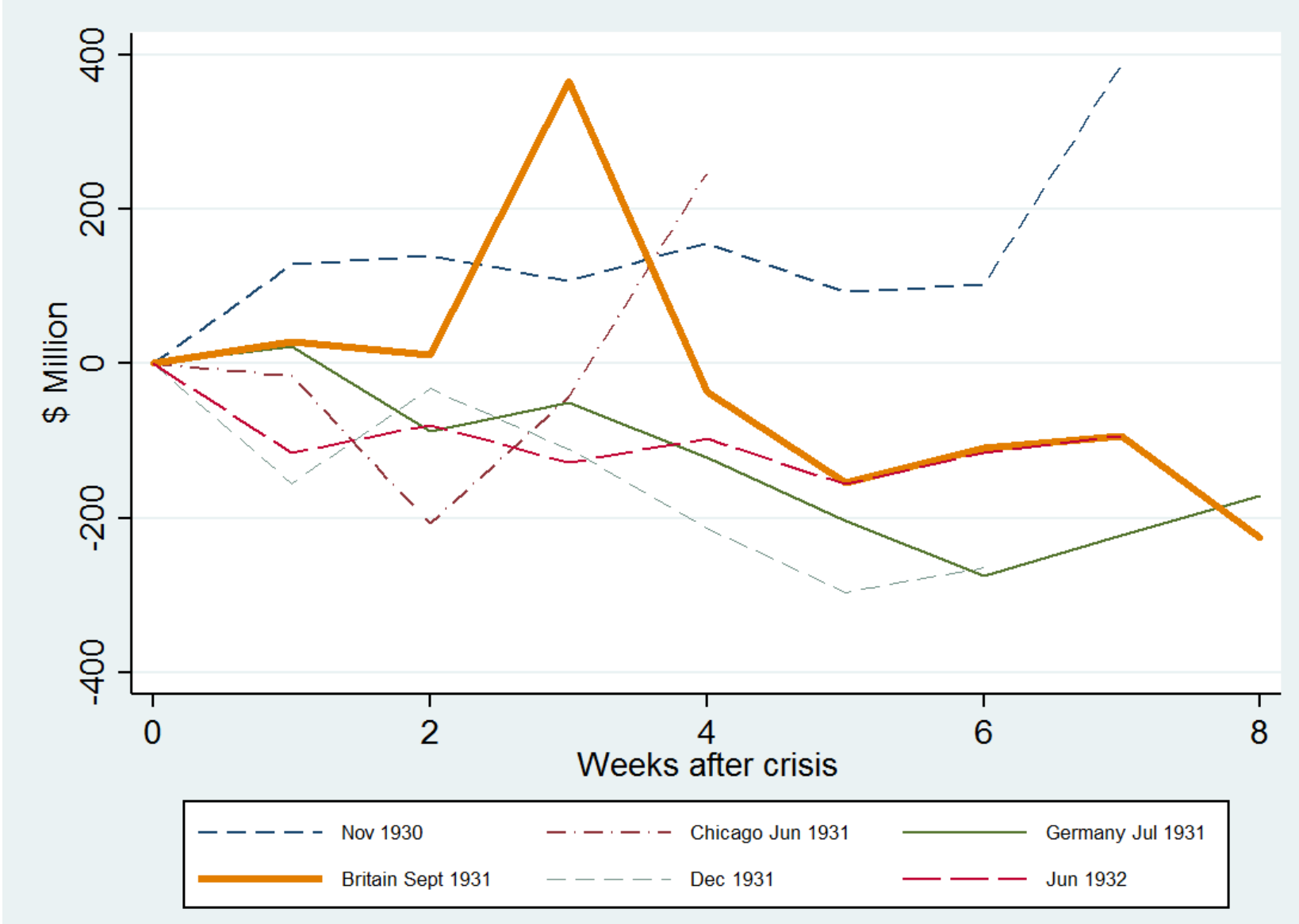

Notes: Panic definitions are described in the text. 
Figure 6. Changes in Demand Deposits in Federal Reserve Districts \& Central Reserve Cities, three Weeks after the Start of Large Banking Panics

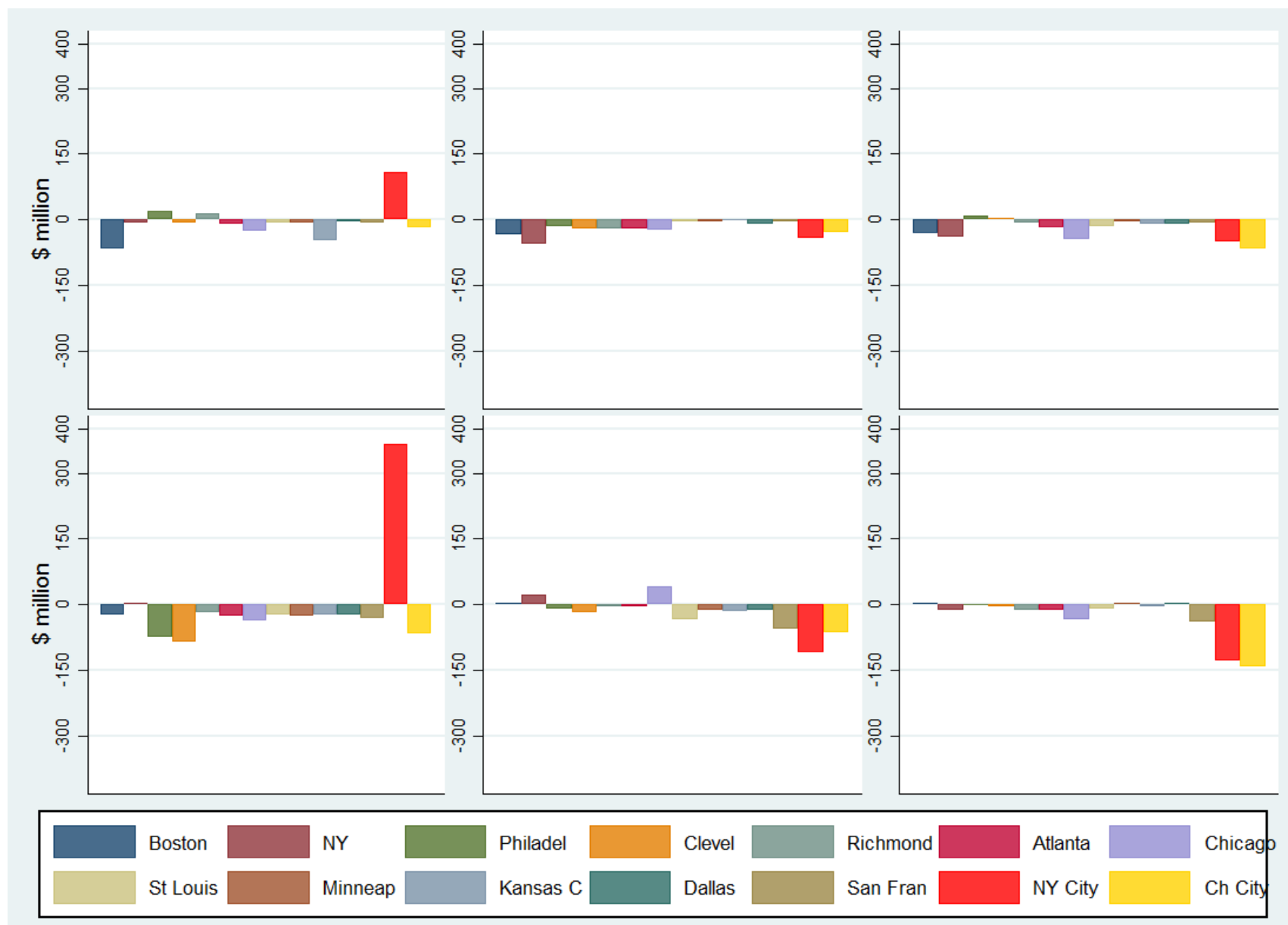

Notes: Figures display changes in the deposits three weeks after the start of the six panics shown in Figures 3-5 and discussed in the text. 
Figure 7. Banking Panics and Changes in Time Deposits in Reporting New York City Banks

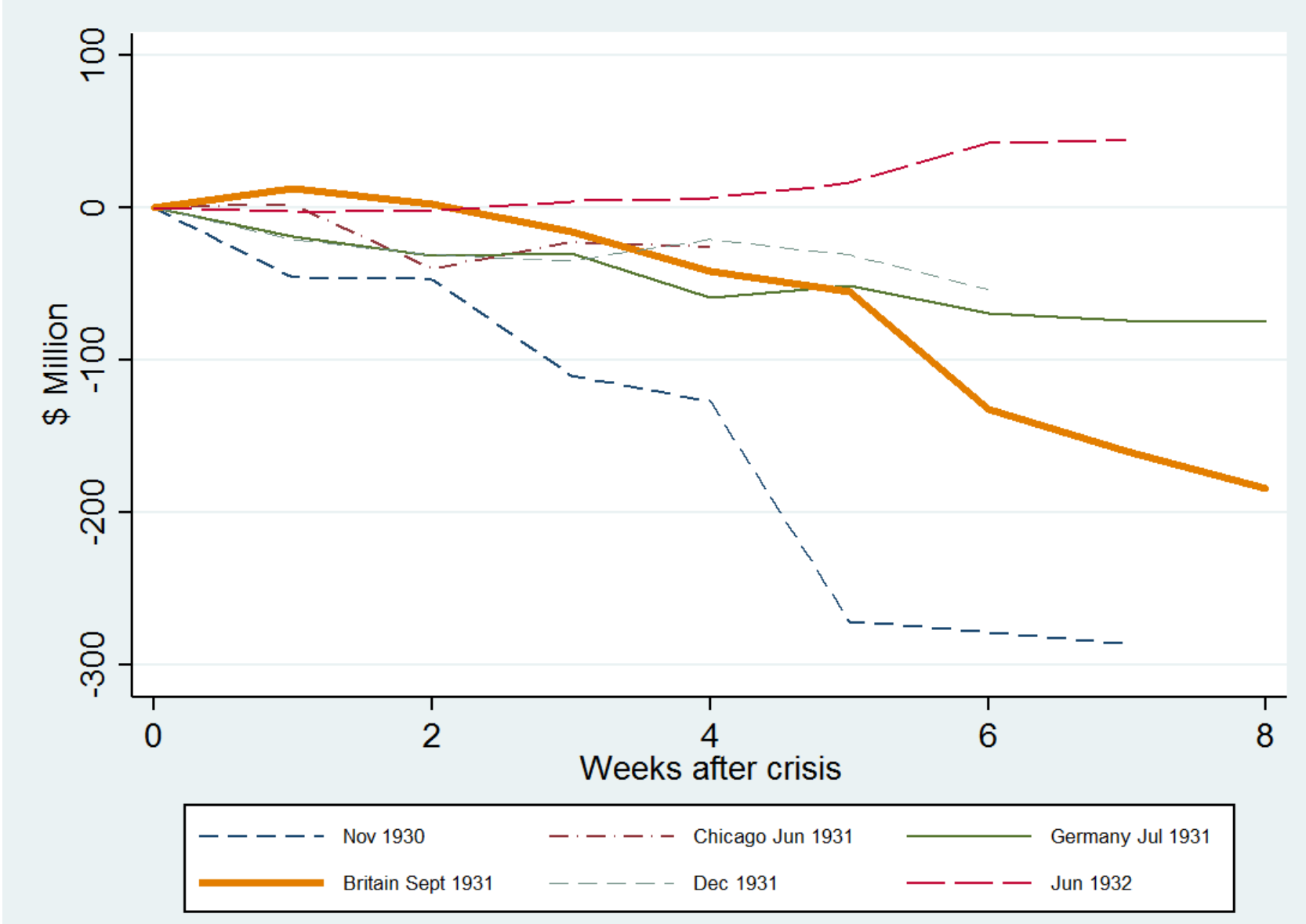

Notes: Panic definitions are described in the text. 
For Online Publication

\section{Appendix A. Data}

This appendix describes data sources and calculations. The description proceeds in the following order: (i) bank balance-sheet information aggregated by call, district, and level of the reserve pyramid; (ii) bank balance-sheet information from weekly reporting banks by district; (iii) micro data on bank distress; and (iv) data used to calculate monetary aggregates by district and call. The bank-balance sheet information extends data introduced by Mitchener and Richardson (2019), which only compiled balance sheets of Fed member banks in reserve and central-reserve cities. In June 1929, those banks held over $95 \%$ of the nations' interbank deposits, but only $46 \%$ of all deposits held in commercial banks and only $39 \%$ of all deposits held in depository institutions (i.e. commercial plus mutual-savings banks). This paper assembles adds new data on Fed member country banks, non-member banks, and mutual savings banks. Adding this coverage allows us to correct for sampling bias in data from weekly-reporting banks. Scholars have long been aware of this existing bias, but have not been able to address it because they lacked information about the underlying sampling process originally used to create the weekly-reporting bank data and/or information about population characteristics to which they could compare the sample.

Our new database on balance-sheets provides benchmarks that can be used to compare the weeklyreporting sample at each call report date, from which we can infer movements in the balance sheets of all banks between those points in time (discussed below). We also describe how we calculate monetary aggregates by Federal Reserve district using methods similar to Friedman and Schwartz (1963), who calculated monetary aggregates for the nation as a whole.

Data on bank balance sheets by Federal Reserve District and by level of the reserve pyramid comes from Banking and Monetary Statistics of the United States, 1914 to 1941 (Federal Reserve Board of Governors 1943, hereafter abbreviated BMS). BMS presents information from the call reports of Federal Reserve member banks aggregated by Federal Reserve District, including counts of banks in each district as well as detailed summaries of assets (15 categories) and liabilities (17 categories) for banks located in reserve cities and for banks located outside reserve cities (called country banks). Book values of loans and investments are reported. BMS also contains detailed classifications of the loans, investments, and deposits of banks from 1928 through 1941. For the second and seventh Federal Reserve Districts, we calculate the balance sheets of banks in the central reserve cities of New York and Chicago by subtracting reserve and country banks from all banks. We check these calculations against tables presenting aggregates of information for central-reserve cities. 
For our analysis, we aggregate data on assets into three categories: (1) lending to businesses (the sum of loans, acceptances, and corporate bonds); (2) lending to the U.S. government (the sum of government securities of varying maturity); and (3) reserves (the sum of cash in the vault and deposits at Federal Reserve banks). We calculate reserves in this manner to conform to the approach used by Friedman and Schwartz (1963), who excluded from their calculations balances at domestic banks (which counted as part of a bank's legally required reserves if deposited in a bank in a reserve or central reserve city) and balances at foreign banks. We also excluded cash items that were in the process of collection from banks' reserves because the slow pace of intercity check clearing left these items simultaneously on the balance sheets of multiple banks; this issue leads to a double counting of presumed reserves. During periods of distress, banks found items in the process of collection generally illiquid and uncollectible (see Richardson 2007 b for details).

Data are for each call date. The nature of the calls raises statistical issues. Many modern time series tests assume observations arise from stable data generating processes with consistent spacing, which is not characteristic of these data. The spacing of the calls was long and variable. In 1929, calls occurred on March 27, June 29, October 4, and December 31; in 1930, on March 27, June 30, September 24, and December 31; in 1931, on March 25, June 30, September 29, and December 31; in 1932, on June 30, September 30, and December 31; and in 1933, not until June 30. Across our sample period, calls occurred an average of every 96 days, but the standard deviation of that average, 35, was high. Restricting the analysis to regularly spaced calls, December and June, eliminates more than half the observations from the data set, leaving six during the Great Depression - far too few to employ statistical tests based on asymptotic arguments. Moreover, the December and June calls almost always occurred on the last day of the month. Banks' balance sheets on these dates may have differed systematically from balance sheets on other dates, when the calls were intentionally unpredictable. We overcome these complications with the methods typical in the literature. We present results assuming the calls were equally spaced. We check this assumption by re-estimating our regression with daily rates of change between calls rather than rates of change between calls, and we obtain similar results.

Data covering the events in the first quarter of 1933 and periods between call reports can be obtained using weekly data on a subset of reporting member banks. The information appears in BMS, Tables 49 and 50. Table 49 presents information for weekly reporting banks in New York City. Table 50 presents information for weekly reporting banks in 100 other cities, including Chicago, all other reserve cities, and approximately 40 other municipalities. The advantages of these data are that they are reported 
consistently over time and at a higher frequency. The disadvantages are that the tables do not present complete balance sheets, only figures for selected assets and liabilities. Moreover, the data come from a non-random set of banks. The chosen banks were meant to create a representative sample, but the sample changes in size over time, as banks merge, fail, or, for some other reason, depart the data set. Changes in the sample occasionally represent changes in the sample composition or sampling methodology. It is impossible to know the size of this problem because the Federal Reserve does not indicate the identities of the reporting banks or the exact proportion of all assets represented by these banks. For the nation as a whole, the Federal Reserve reports that they attempted to keep that proportion around $70 \%$. When we compare the weekly reporting data for New York City for the last week of 1932 to the call report data from the same week (although on a different day), we find that the interbank balances for the weekly reporting banks represented 82 percent of all interbank balances in the city. The fraction of other components of the balance sheet represented by weekly reporting banks ranges from 74 percent (net demand deposits) to 96 percent (reserves with the Fed).

Weekly reporting data for the twelve Federal Reserve districts and from the city of Chicago comes from the Federal Reserve Bulletin. Tables with this information appear from roughly 1919 through 1939. After digitizing these data, we created consistent balance-sheet categories using the procedures outlined in BMS. The weekly-reporting banks represented a different share of banking resources across districts and over time. For example, in one district at one date, the weekly-reporting banks might contain $40 \%$ of all bank deposits whereas at some other date they might contain $60 \%$ of all deposits or, in some other district, they might constitute $80 \%$. These differences arose due to differences in sample composition across districts and over time. We offset these differences and create a weekly-reporting data set that accurately depicts aggregate movements in bank balance sheets using district-level call-report data from BMS. At each call date, BMS reports bank balance-sheet information aggregated by Fed District. These aggregates are totals for the population from which the weekly-reporting data samples. Comparing the call-report and weekly-reporting data reveals how much we need to scale up the weekly-reporting data to recover accurate aggregate values. Weekly-reporting data was collected on Wednesday of each week. Call reports could be collected on any weekday. In weeks with call reports, we create the scale- up factor using the call-report data that from that week. In weeks without call reports, we create the scale-up factor by linearly interpolating between scale-up factors from weeks with call reports.

Linear interpolation enables us to calculate aggregate balance sheets week-by-week using the formula: 


$$
\begin{aligned}
& X_{z i c t}^{\text {All Banks Estimated }} \\
& \quad=\left(\left(1-t / T_{c}\right)\left[X_{z i c}^{\text {All Banks in Call Report }} / X_{z i c}^{W R \text { Banks }}\right]\right. \\
& \left.\quad+t / T_{c}\left[X_{z i, c+1}^{\text {All Banks in Call Report }} / X_{z i, c+1}^{W R \text { Banks }}\right]\right) X_{z i c t}^{W R \text { Banks }}
\end{aligned}
$$


member banks in district $i$ in week $c t$. The letter $c$ indexes weeks with call reports. The letter $t$ indexes weeks from one call report to the next. Since the number of weeks varies between call reports, dating entails complicated notation. For each $c$, the sequence $t(c)$ indexes weeks beginning with call-report date $\mathrm{c}$ and ending with call-report date $c+1$, where $\mathrm{t} \epsilon\left[0,1, \ldots, T_{c}\right]$. The week indicated $c 0$ is the week of call $c$. The weeks indicated by $\mathrm{c} 1$ to $c, T_{c^{-}} 1$ are the weeks between the call dates $c$ and $c+1$. The week indicated $\mathrm{c} T_{c}$ is the week of call $c+1$. It can also be denoted as week $c+1,0$, which is the initial week of the interval beginning at call $c+1$ and ending at call $c+2 . X_{z i c}^{\text {All Banks in Call Report }}$ is the aggregate total in the call report of balance sheet item $z$ for all Fed-member banks in district $i$ at the call report date c. $X_{z i c}^{W R}$ Banks is the total for all weekly reporting Fed-member banks of balance sheet item $z$ in district $i$ in the week of call report $c$. Note that for simplicity, we dropped the 0 at the end of the date $c 0$ when describing data from weeks with call reports. $X_{z i c t}^{W R}$ Banks is the total for all weekly reporting Fed member banks of balance sheet item $z$ in district $i$ in week $c t$.

The most accurate source for information about bank suspensions and failures during this period is the micro-level data from the Board of Governors' bank suspension study. These are described in Richardson (2007a, 2008). The Board's Division of Bank Operations completed a form ST 6386b for each bank that suspended operations. From these forms, we extract an array of information: a bank's location, whether it was a Fed member or non-member, whether it possessed a state or national charter, the date of its suspension, the date of its reopening (if any), the deposits that it possessed on the date of suspension, whether it was suspended by a decision of its board of directors or under the authority of a state or national bank examiner, and whether it suspension was triggered by a run. The latter piece of information was elicited by asking opinions of examiners and other authorities and according to the assessment procedures used by the division of bank operations. Documents describing these procedures indicate that while depositors lined up outside a bank pleading to withdraw funds was one symptom of a run, the determination of whether a run occurred should be based upon the volume of withdrawals and their impact on the bank as well as evidence of significant withdrawals via check or wire transfer which usually occurred before ordinary individuals panicked over the safety of their funds. Researchers at the Federal 
Reserve called these events "invisible runs." For 1929-32, we tabulate the ST 6386 micro data by call date and Federal Reserve district, creating an accurate analog for our panel of bank balance sheets by call date.

To calculate monetary aggregates by Federal Reserve district, we collect information on deposits, reserves, and currency in circulation from numerous sources. Data on deposits comes from BMS (described above) and the Federal Reserve Bulletin (FRB). The Bulletin's issues in January and July 1930; January, April, and October 1931; January and April 1932; and January 1933 contain a table titled "Conditions of All Banks in the United States: Table 1 - All banks in the United States - Principal Resources and Liabilities, on Call Dates, by Federal Reserve Districts." From this table, we obtain data from member and non-member banks at each national-bank call date. The data for national and member banks was aggregated from call reports delivered to the Fed and the Comptroller of Currency. The table's notes indicate that data on non-member banks at those dates comes from state authorities. In some cases, it is tabulations of data from calls by state authorities on those dates. In other cases, it is totals that state authorities calculated from other sources at their disposal. The table includes information on all national and state commercial banks, including stock and mutual savings banks, and all private banks under state supervision. Note that this figure is the sum of net demand deposits, time deposits, and government deposits, excluding interbank deposits. We do not have sources for non-member banks at call dates that separate demand from time deposits, so our estimates of the money stock include both. Our calculations, in other words, replicate Friedman and Schwartz's (1963) money supply estimates including time, demand, and mutual savings deposits (a figure now known as M3) and their estimate including only time and demand deposits (a figure now known as M2).

The data on deposits described above covers all calls from 1929 through 1932. Unfortunately, national authorities and most state banking departments did not call for reports of condition from January to June 1933. We must, therefore, estimate the change in aggregate deposits over the first six months of 1933, and do so using methods similar to Friedman and Schwartz (1963). For member banks in each district, we begin with the data series from weekly reporting banks in each district. We then scale-up the variables net demand deposits, time deposits, and government deposits for the reporting date March 29, 1933, and sum the results. For non-member banks in each district, we first calculate the ratio of members to non-members deposits at call dates in June, September, and December 1932. The product of (a) the average of these three ratios and (b) total deposits in member banks on March 29, 1933 is our estimate of deposits in non-member banks on this date. 
Distinguishing M2 from M3 requires information on deposits in mutual savings banks. These deposits were concentrated in a few Fed districts, primarily in the northeast. These data come from All Bank Statistics (Board of Governors 1959, henceforth denoted ABS), which provides information on deposits in mutual savings banks by state. We create totals by summing the states within each Fed district. We divide states that are split between Fed districts using the population weight method introduced by Park and Richardson (2012). Data in ABS are at an annual frequency, reported for June 30 (or the nearest available date), and thus give us a precise call for June; other calls are estimated by linear interpolation. The value for a call between two Junes is the average of those June values, with the beginning and end points weighted by the fraction of time that passed between them. Readers should note that most deposits in mutual savings banks were held in the Boston $\left(1^{\text {st }}\right)$ and New York $\left(2^{\text {nd }}\right)$ Federal Reserve districts. Mutual savings deposits in the other ten districts were low or zero. In those ten districts, our estimates of M2 and M3 are, for all practical purposes, identical.

Correctly calculating the money supply requires information on checks in the process of collection, commonly called "float." For member banks, data for items in the process of collection for each district at each call date appears in BMS. Direct sources of these data do not exist for non-member banks. ABS compiled the extant state-level information to generate data on items in the process of collection on June $30^{\text {th }}$ of each year. ABS notes, however, that for many states, their figures are estimates, not compilations from comprehensive survey data. Information from ABS serves as the basis for estimating float for state non-member banks. We employ two additional pieces of information. The first is the national aggregate value of cash items in the process of collection for state commercial banks (reported in ABS reports for June $30^{\text {th }}$ of each year). We estimate its value at the intervening calls via linear interpolation. The second is float of member banks by district and by call date reported in BMS), which we use to calculate the share of member-bank float in each district, at each call. The share is high (between $50 \%$ and $70 \%$ of all float) in the New York district, about $10 \%$ in the Chicago, and smaller in the other districts. The relative shares are due, in part, to the difference sizes of the banking systems in the different districts and probably also to differences in the accounting practices in different states. We allocate total float for state-chartered commercial banks across Fed districts using their shares of member bank float at each call date.

Our method is a reasonable facsimile of the method of Friedman and Schwartz. Non-member float is the coarsest component of our calculations, but it has little impact on our aggregate calculations primarily because non-member banks report little float before and during the Great Depression. The explanation for this fact lies in accounting practices of state-chartered, non-member banks, who cleared 
most of their checks through correspondents, and typically listed checks in the process of collection as interbank deposits. Since we have already excluded interbank deposits from our calculations we have, in effect, also excluded most float for state-chartered non-member banks. For more information about accounting procedures and the difficulty of calculating float, see Richardson (2007b) which discusses these issues in detail.

Data on member-bank reserve balances comes from the Federal Reserve Bulletin (FRB) and the Annual Report of the Federal Reserve Board (FRAR). For 1929, 1930, and 1931, FRAR contains a table titled "Principal Resources and Liabilities of Each Federal Reserve Bank, by Weeks." The table number varies by year of publication: Table No. 72 in 1929, Table No. 78 in 1930, and Table No.83 in 1931. The tables indicate member bank reserve balances by district for each Wednesday. We select data from the Wednesday closest to the corresponding call-report date. For June and September 1932, the data come from the table in FRB titled "Each Federal Reserve Bank - Resources and Liabilities" in the section "Federal Reserve Statistics by Districts." For December 1932, data come from FRAR, "Table No. 16 Condition of Each Federal Reserve Bank at the End of 1931 and 1932." For March 1933, we estimate reserves with the Fed using data on weekly reporting banks for each district. We scale up the reserves reported on March 29, 1933 using the proportion total reserves actually held by those reporting banks on the call-report date in December 1932.

Data on currency, coin, and other forms of money in circulation comes from Federal Reserve publications. For the years 1929 through 1931, data on Federal Reserve Bank notes comes from the FRAR. The information appears in a table entitled "Principal Resources and Liabilities of Each Federal Reserve Bank, by Weeks." The table's number varies by year of publication: table 72 (1929); table 78 (1930); and table 83 (1931). Data on notes in circulation by district is available for each week on Wednesday. We choose data from the Wednesday closest to the corresponding call date. For most of 1932 and 1933, we gather data on Federal Reserve Bank notes from issues of the FRB published in July 1932, October 1932, and May 1933. These issues contain a table entitled "Reserves, Deposits, Note Circulation and Reserve Percentages" in the section "Federal Reserve Statistics by Districts." Again, we choose data from the Wednesday closest to the corresponding call date. For the call in December 1932, we draw data from the FRAR, "Table No. 16 - Condition of Each Federal Reserve Bank at the End of 1931 and 1932."

In the 1920s and 1930s, substantial quantities of legal money issued by entities other than Federal Reserve Banks remained in circulation. This money included national bank notes, Treasury gold and silver certificates, gold coins and bullion, coins minted from other metals, and an assortment of miscellaneous 
historical currencies and Treasury obligations, such as greenbacks issued in the Civil War. Information on these non-Fed monies appears in the FRAR. We typically take it from a table titled "Kinds of Money in Circulation." The table's number varies by year of publication: table 31 in 1929, table 35 in 1931 (used for data for 1930 and 1931), table 52 in 1932, and table 56 in 1933. We use data from the columns (a) Total, (b) Federal reserve notes, and (c) Federal reserve bank notes. Aggregate non-Fed money equals column (a) minus columns (b) and (c).

These data are available only in aggregate. We allocate it across Fed districts using an assumption from Friedman and Schwartz: economic agents were indifferent between Federal Reserve and non-Federal Reserve notes. This assumption seems reasonable. Fed and non-Fed notes had the same value. Laws treated both as legal tender for all debts public and private. All were obligations of the Federal government. There is no evidence that anyone thought the federal government would default or devalue one type of note but not the others. There is no evidence that they ever traded at different values or that the public differentiated their values in any substantive way. Given this assumption, Friedman and Schwartz argue all types of money should circulate at the same velocity, which was a requirement underlying their construction of a single set of economy-wide monetary aggregates. That assumption underlies all subsequent estimates of the money supply, including ours. It has a close corollary: non-Fed money should be distributed across districts in the same proportions as Federal Reserve notes. This equilibrium should have arisen because note changed hands frequently, typically twice each week for denominations frequently used in transactions, such $\$ 1$ and \$5 notes; about once a week for larger notes such as $\$ 20$ and $\$ 50$; and about once a month for larger $\$ 100$ notes (Feige, 1989). As all of these notes change hands frequently, they should spread across the United States, in the same pattern as Federal Reserve notes.

Based upon this argument, we estimate non-Fed money in each Fed district as follows. Using data descried earlier, we first calculate each district's share of all Federal Reserve notes in circulation at each call date. Then, we multiply that share by the nationwide aggregate supply of non-Fed money. The product is the supply of non-Fed money in each district at each call date.

Given the discussion above, it is worth observing that notes of a particular Federal Reserve Bank contribute only to the money supply in its own district. The Federal Reserve System was designed so that each Reserve Bank would hold the gold needed to back the money required for economic activity in own district. During the first few decades of the Fed's existence, each Federal Reserve Bank thus issued its own notes backed by its own assets. The gold constraint for each reserve bank bound individually, meaning the $1^{\text {st }}$ Federal Reserve District needed enough gold in its vaults to support the currency that it 
had in circulation, as did the $2^{\text {nd }}$ district, and so on. The same was true, of course, for reserve deposits, which also had to be backed in part by gold.

Of course, money and bank deposits did not stay put. Payments flowed constantly across districts. An individual might, for example, withdraw \$10 from a bank account in New York City at lunch time and spend that \$10 note issued by the Federal Reserve Bank of New York at a restaurant near their house in Connecticut (which was in an adjacent Fed district) in the evening. The Federal Reserve System was designed to accommodate these flows and to ensure that gold flowed along with currency, so that the monetary base was distributed efficiently to support economic activity in the different districts. Two simple mechanisms balanced these flows. The first was a rule that prohibited Reserve Banks from disbursing notes of other Reserve Banks. The second was the practice of making repayments between Reserve Banks in gold via the inter-district settlement fund.

We explain the impact of these mechanisms by continuing our example. The restaurant in Connecticut, which received $\$ 10$ note deposited in their bank, would in turn deposited the note at the Federal Reserve Bank of Boston. The Boston Fed could not pass that note on to another person or institution. Instead, the law required the Boston Fed to return that note to the New York Fed. In return, Boston received $\$ 10$ of gold from the New York Fed. These rules and practices ensured that as Fed notes flowed from one Fed district to another, gold reserves (and thus the monetary base and the money supply) would decline in the former and expand in the latter. These flows would persist until changes in the relative sizes of the money supplies in the two districts returned the system to equilibrium.

Using the data described above, we calculate monetary aggregates for each Federal Reserve district for each call date with the following formulas:

(A.1) $C=C_{F e d}+C_{n o n-F e d}$

(A.2) $D=D_{F e d}+D_{\text {non-Fed }}$

(A.3) $B=R+C$

(A.4) $M=D+C$

(A.5) $m=M / B$

(A.6) $c=D / C$

(A.7) $r=D / R$,

where $C$ is currency, $C_{F e d}$ is Federal Reserve notes in circulation, and $C_{n o n-F e d}$ is non-Fed monies in circulation. $D$ is total deposits at commercial banks, $D_{F e d}$ is deposits in Fed member banks, and $D_{\text {non-Fed }}$ is deposits in non-member banks. $B$ is defined as monetary base and $\mathrm{R}$ is Fed-member bank reserve balances. 
$M$ is the money supply. Thus, the money multiplier, $m$, is $M / B$ and the currency-to-deposit ratio, c, is $D / C$. Finally, the reserve-to-deposit ratio, $r$, is $D / R$.

\section{Appendix B: Specification of Matrices for the Calculation of Aggregate Changes in Lending}

The matrices $B_{1}^{\text {time }}$ and $B_{1}^{\text {demand }}$ have 12 rows and 38 columns. Elements of the matrices indicate how suspensions during panics in district $i$ influenced flows of demand and time deposits into and out of banks in district $j$. The units of observation (the $i$ 's described earlier) are aggregates of member and nonmember banks at different levels of the reserve pyramid in each Federal Reserve district. Using the notation from Equation (1) in the main text, the elements of the matrix for time deposits are:

(B. 1) $\mathrm{B}_{1 \mathrm{ij}}^{\text {time }}=\beta_{1}^{\text {member }}$ if $i=j$ and $j \leq 12$.

(B. 2) $\mathrm{B}_{1 \mathrm{ij}}^{\text {time }}=\beta_{1}^{\text {nonmember }}$ if $i+12=j$ and $13 \leq j \leq 24$.

(B. 3$) \mathrm{B}_{1 \mathrm{ij}}^{\text {time }}=\beta_{1}^{\text {member }}+\beta_{1 R}^{\text {member }}$ if $i+24=j$ and $25 \leq j \leq 36$.

(B. 4) $\mathrm{B}_{1 \mathrm{ij}}^{\text {time }}=0$ if $i \neq j$ and $j \leq 36$.

(B.5) $\mathrm{B}_{1 \mathrm{ij}}^{\text {time }}=\beta_{1}^{\text {member }}+\beta_{1, C R}^{\text {member }}$ if $i=j=37$

(B. 6) $\mathrm{B}_{1 \mathrm{ij}}^{\text {time }}=0$ if $i \neq 37$ and $j=37 \mathrm{a}$

(B. 7) $\mathrm{B}_{1 \mathrm{ij}}^{\text {time }}=0$ if $j=38$

For member banks, estimates of the $\beta$ parameters appear in Tables 3 and 4. For nonmember banks, estimates of $\beta$ appear in Table 5. The subscript 1 indicates that the $\beta$ coefficients are the ones estimated for panic suspensions. In the notation for equation (1) from the text, the coefficients on deposit flows that coincided with non-panic suspensions were indicated with the subscript 2.

The matrix for demand deposits is similar. For $i \leq 12$ and $i \geq 23$, the structure of the demanddeposit matrix is identical to the structure of the time-deposit matrix, except the $\beta$ coefficients in the demand-deposit matrix come from our estimation of demand-deposit outflows caused by banking panics. For nonmember banks, we set the $\beta$ coefficients in the demand-deposit matrix equal to zero. This setting is for computational convenience. Data for nonmembers only indicates the sum of time and demand deposits. We estimate how bank suspensions influence this sum, and we incorporated that estimate in the time deposit matrix. We place zeros in the demand deposit matrix to avoid double counting. Our calculation would not change if we inverted the incorporation of nonmember flows, placing the estimated flow in the demand-deposit matrix and zeros in the time-deposit matrix or if we split the coefficient in any convex combination across the matrices. In other words, our estimate of aggregate lending would be the 
same if we inserted $\Theta * \beta$ into the time-deposit matrix and $(1-\Theta) * \beta$ into the demand-deposit matrix for all $\Theta$ from 0 to 1 .

Appendix C: Relationship Between the National and Federal-Reserve District Level Money Multipliers

Given equations (A.1) - (A.7), we can derive relationships between the national and Fed-districtlevel monetary aggregates. Aggregates for the $i^{\text {th }}$ Federal Reserve district are indicated by the subscript $i$. Therefore,

(C.1) $M_{i}=C_{i}+D_{i}$ and

(C.2) $B_{i}=C_{i}+R_{i}$.

National monetary aggregates, which are sums of district-level aggregates, have no subscripts. Therefore, (C.3) $M=\sum_{i} M_{i}$ and (C. 4) $B=\sum_{i} B_{i}$.

The money supply in each district is generated from the monetary base via deposit expansion in each district:

(C.5) $M_{i}=m_{i} B_{i}$.

The national money multiplier, $m$, is a function of the money multipliers in the twelve Fed districts, as indicated by equation:

$$
\text { (C. 6) } \begin{aligned}
m=\frac{M}{B}=\frac{\sum M_{i}}{\sum B_{i}} & =\frac{\sum M_{i}\left(\frac{B_{i}}{B_{i}}\right)}{\sum B_{i}}=\frac{\sum \frac{M_{i}}{B_{i}}\left(B_{i}\right)}{\sum B_{i}}=\frac{\sum m_{i}\left(B_{i}\right)}{\sum B_{i}} \\
& =\sum m_{i}\left(\frac{B_{i}}{\sum B_{i}}\right)=\sum m_{i} b_{i},
\end{aligned}
$$

where $\mathrm{b}_{\mathrm{i}}=B_{i} / \sum B_{i}$ is the fraction of the national monetary base in the $\mathrm{i}^{\text {th }}$ Federal Reserve District. The change in the national monetary base, $\Delta \mathrm{m}$, is a weighted sum of the change in the money multipliers in the twelve districts, expressed as:

$$
\text { (C. 7) } \Delta m=\sum \Delta m_{i} b_{i}
$$

The weights are each district's share of the national monetary base.

The derivation of equation (C.7) assumes changes in a district's money multiplier, $m_{i}$, do not trigger changes in a district's share of the monetary base, $b_{i}$. This assumption held during our sample period since Fed districts seldom loaned substantial reserves to each other. For example, Chicago declined 
New York's request to borrow reserves during the financial panic preceding the banking holiday. If Chicago had accommodated New York, we would need to adjust our calculation to reflect the fact that the decline in the money multiplier in New York (which is the manifestation of a panic in this data) triggered an increase in its monetary base. We have found, however, no clear instances of such actions and no interdistrict loans large enough to impact our aggregate calculations.

Equation (C.7) is the basis for equation (5) in the body of the paper. We go from the former to the latter by adding a time subscript, which indicates that the equation holds at every point in time. In our application, this means it holds at each call date. We replace the change in each district's multiplier, $\Delta m_{i}$, with our estimate of this change, $\widehat{m}_{i t}$. The latter is the product of $\beta_{\text {panic }}$, which is the estimated impact of a bank suspension in district $i$ on the multiplier in district $i$, and $S_{\text {panic,it }}$, which is the number of suspensions in district $i_{-}$from call $t$ to call $\mathrm{t}+1$.

Given the equations above, we can we can write the national aggregate money supply as:

(C. 8) $M=m B=\left(\sum m_{i} b_{i}\right) B$.

Changes in the national aggregate money supply are linked to changes in district multipliers by:

(C. 9) $\Delta M=\Delta m B=\left(\sum \Delta m_{i} b_{i}\right) B$.

Equation (C.9) links the change in the national money supply to our estimates of how panics influenced the money multiplier in each Federal Reserve District.

\section{Appendix D. Estimated Effects on the 1933 Banking Panic}

The panel methods that we employ in the body of our paper cannot directly address the impact of the nationwide banking panic in the winter of 1933 because the call-report data that we use for our estimates do not exist for that period. The government did not collect it. Our methods and additional assumptions can be used indirectly, however, to estimate the panics' effect on bank lending and monetary aggregates. (Note that the equations we refer to correspond to those in the body of our paper.)

Figures D1 and D2 illustrate the severity of the panic of winter 1933. Figure D1 plots weekly changes in deposits for 100 reporting cities, excluding New York. Demand deposits declined by $\$ 1.078$ billion and time deposits declined by $\$ 973$ million. As Figure D2 shows, the panics’ impact in New York was even larger. From January 18 to March 8, demand deposits declined by $\$ 1.364$ billion and time deposits declined by $\$ 165$ million in reporting New York City banks.

To estimate this panic's effects, we use out-of-sample forecasts. The forecast for bank lending uses equation (3) and assumes the coefficients estimated with data up until the end of 1932 also apply to 
January, February, and the first week of March in 1933. Multiplying these coefficients and number of banks that suspended operations in that period yields our estimate of the decline in bank lending associated with those suspensions. Results appear in Table D1. The decline in lending for nonmember banks averaged across the six specifications is $\$ 203$ million. The decline in lending for member banks averaged across the six specifications is \$188 million. We add these estimates to those for the period from 1929 to 1932 to arrive at a bottom-line estimate of the fraction of the decline in bank lending due to banking panics.

Our estimate seems reasonable, given that weekly reporting member banks outside of New York City reported a decline in total loans and investments of $\$ 365$ million between January 4 and March 1, 1933 - two days before the start of the nationwide banking holiday. Substantial uncertainty, however, exists about changes in bank balance sheets during the financial crisis that led to the banking holiday. Call report data exists for all banks in the United States for the last business day in December 1932. Call data was not collected again until June of 1933. Weekly reporting data outside New York City reveal large declines in bank deposits and lending between March 1 and March 8, but some of that decline occurs when banks were closed during holidays. It is unclear why deposits and lending decline. Some of the decline may be due to changes in the number of banks in the weekly sample. (In an early paper, Mitchener and Richardson (2019), we use the weekly reporting data to provide a maximal estimate of the decline in loans and investments at commercial banks in the crisis preceding the banking holiday. Our estimate is a decline of $\$ 4.6$ billion.)

Our out-of-sample forecast may underestimate the decline in lending due to the panic in the winter of 1933 because we assume that the impact of a bank during that panic equaled the average impact of a bank suspension over the previous three years. By all accounts, however, the 1933 panic was more severe than earlier events. We further assumed that banks suspensions of the type we measured from 1929 through 1932 accurately depict the severity of events in the winter of 1933 even though proclamations by state and local governments partially or completely shut down commercial banks in more than 20 states in early 1933. These government closures of banks do not appear in our data. As a consequence, the inputs to our out-of-sample forecast probably undercount the number of panic-period suspensions in winter 1933, and likely underestimate their impact on lending.

Thus, to better gauge the panic in the winter of 1933, the bottom portion of Table D1 provides a range of estimates based upon escalating assumptions about the severity of the event. The first row assumes that the panic of 1933 induced declines in lending in each district equal to the average of the panics in which more than 20 banks failed in that district between 1929 and 1932 . We calculate this 
amount by determining, for each district, the call periods in which more than 20 banks failed during panics, determining the decline in lending due to the panics during each of these call periods, averaging those figures, and applying them to the 1933 panic. ${ }^{37}$ This conservative assumption yields results similar to our out-of-sample forecast.

The second row of Table D1 assumes that the number of banks failing in a district during the panic of 1933 equaled the average number of banks failing during panics in that district from 1929 to 1932 . We calculate this amount by averaging the number of banks that failed during panics and use this value in our out-of-sample forecast rather than the number of suspensions actually reported in our data set. The third row assumes that the number of banks failing during the panic of 1933 equaled the maximum number of banks failing during a panic in each Fed district from 1929 to 1932 . We then use this figure in our out-ofsample forecast rather than the number of suspensions actually reported in our data set.

The last row of Table D1 assumes that all of the decline in lending in the winter of 1933 was due to the panic. To estimate this amount, we calculate the decline in loans and investments of weekly reporting Fed member banks in each Federal Reserve district from December 31, 1932 to March 8, $1933 .{ }^{38}$ We then determine the ratio of loans and investments in each district held by all commercial banks and by Fed member weekly reporting banks at the last call date in December 1932. Then, we multiple the former and the latter to provide an estimate of the decline in lending in each district in the winter of 1933 and sum the district subtotals to arrive at the national total.

Overall during the Great Depression, we find that deposit drains during banking panics substantially reduced lending by banks. From July 1929 to December 1932, panics reduced lending by $35 \%$ to $40 \%$. When considering the panic in the winter of 1933, data limitations obscure the picture and increase uncertainty. Reasonable assumptions about the severity of the panic in 1933 indicate that from peak (summer 1929) to trough (winter 1933), panics reduced bank loans and investments by $35 \%$ to $40 \%$. Maximalist assumptions suggest that the aggregate impact was larger, with panics reducing commercial bank lending by $50 \%$ to $54 \%$.

\footnotetext{
${ }^{37}$ Note that the definition of a panic suspension, the number in each call period, and their impact on lending vary across the specifications in Table 7.

${ }^{38}$ Of course, this method assumes that lending declined at all commercial banks at the same rate as it declined at Fed member weekly reporting banks. Readers should note the moderate declines in lending for weekly reporting banks outside New York, which seems odd given the severity of the panic, as well as the unexplained dramatic decline in lending by weekly reporting banks from March 1 to March 8, which seems odd given the shutdown of many state-chartered systems and the fact that the national banking holiday began on March 5. We know of no reports or research that explains these paradoxical patterns. So, we work with the data reported in contemporary sources.
} 
We next consider the effects of the panic of 1933 on the money multiplier. Table D2's penultimate row indicates changes in the money multiplier during the final banking crisis of the Great Depression, from January through March 1933. We do not have data on deposits (or other changes in balance sheets) of many commercial banks during this period. While state and federal authorities collected reports of condition from banks on the last business day of December 1932, they did not request call reports in March 1933. The Comptroller of Currency resumed collecting data in June, as did some states, but others, including New York, did not collect or disseminate data for longer periods. We overcome this lacuna using an assumption similar to Friedman and Schwartz's, who assumed that deposits in all banks declined by the same percentage as weekly reporting banks throughout the United States. We assume that deposits in all banks in each Fed district declined by the same percentage as deposits in the weekly reporting banks in that district. With this assumption and extant information on currency in circulation and reserve-bank balance sheets, we calculate monetary aggregates for each district and the nation as a whole.

The predicted change is calculated via equation (5). This calculation requires explanation and caveats. It is an out-of-sample forecast because the coefficient $\beta_{\text {panic }}$ is estimated for the period in which we have call report data, 1929 - 1932. The total number of suspensions, $S_{\text {panic,it }}$, comes from the same data source as for earlier periods. Panic suspensions are defined in the same way, but this value does not capture the large number of banks that suspended operations in February and March due to local and state government declarations of banking holidays.

Despite these limitations, the calculation conveys a clear message. The decline in the money multiplier from January through March 1933 appears to be entirely due to the banking panic sweeping the nation. Our bottom line indicates that banking panics induced almost all of the decline in the money multiplier during the Great Depression. 
Appendix Table D1. Aggregate Impact of Panics on Commercial Bank Lending and Investment Including Panic of 1933

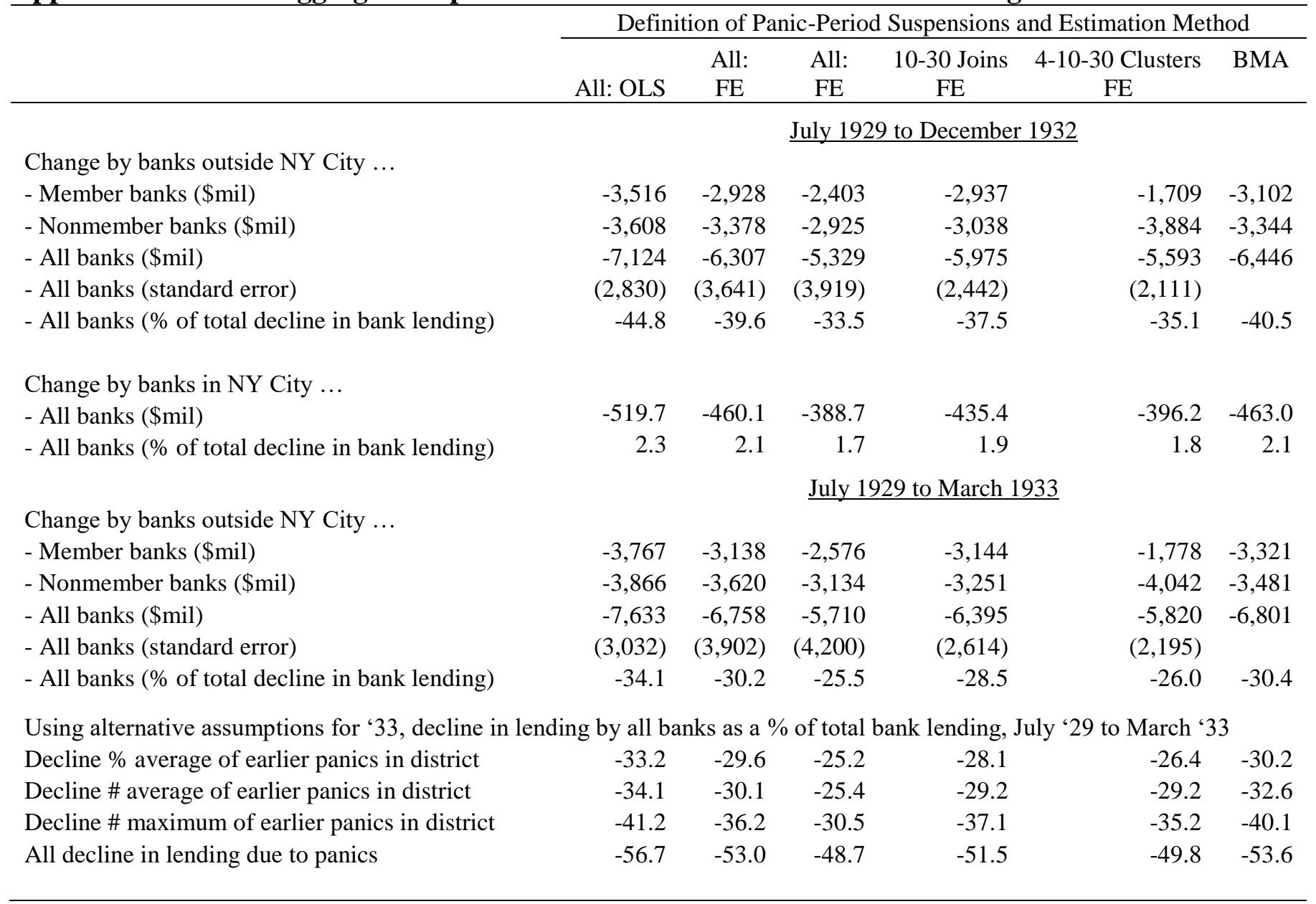

Notes: Standard errors are bootstrapped. See the text for details on calculations. Lending for member banks includes both loans and corporate bonds. Lending for non-members includes loans, corporate bonds, and government bonds. Alternative assumptions for 1933 described in text. FE indicates fixed effects estimation method. 


\section{Appendix Table D2: Effects of Banking Panics on Monetary Aggregates including Panic of 1933}

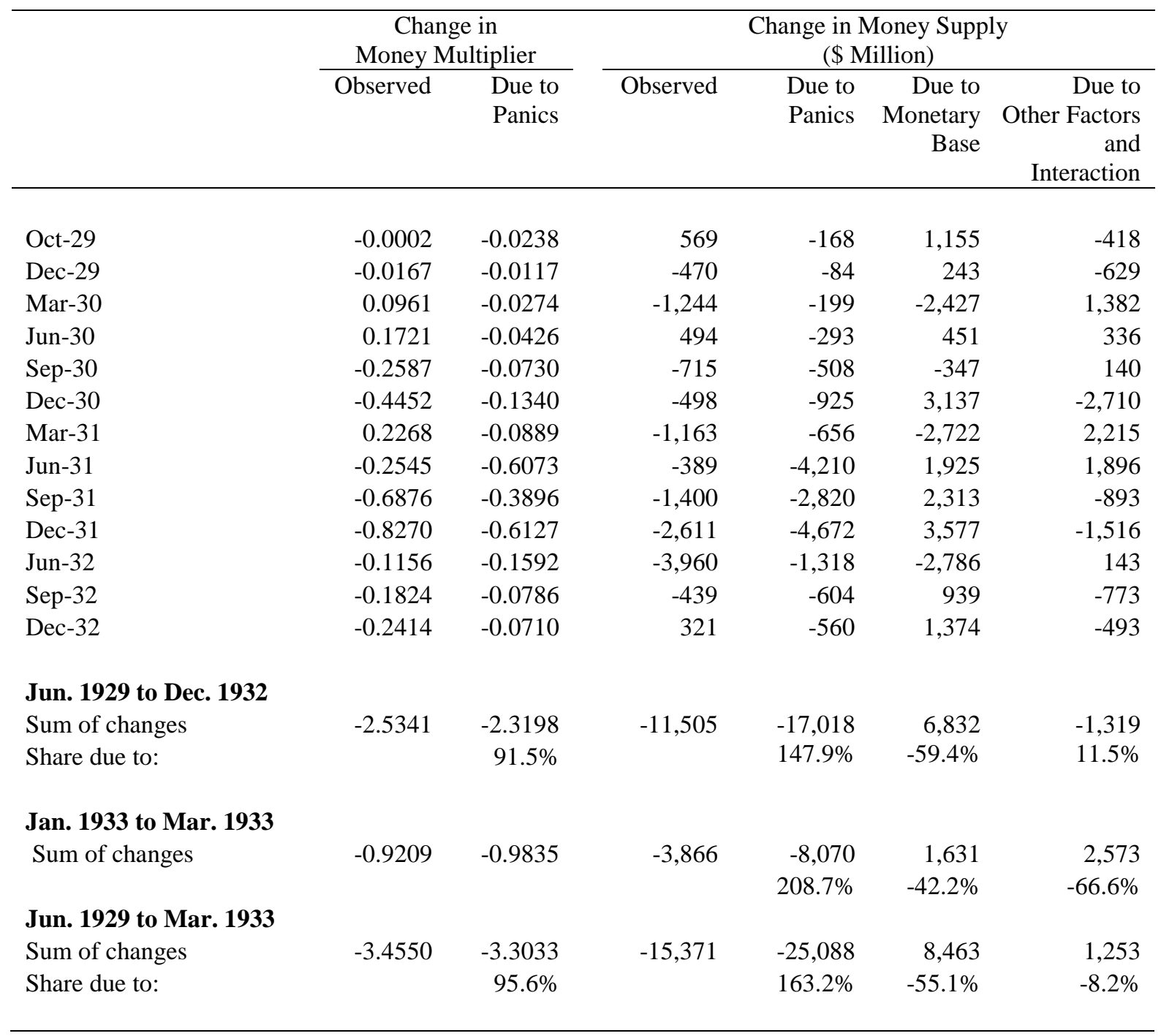

Notes: Column 1 indicates the month and year at the end of a call-report interval (i.e. date t). Columns 2 and 4 report observed changes from t- 1 to $t$ in our data on monetary aggregates at the call-report frequency. Columns 3 and 5 indicate our estimate of how panics impacted monetary aggregates (based on equations 5 and 6). Column 6 equals column 3 minus columns 4 and 5. Sum of changes slightly overestimates total change due to compounding. 


\section{Appendix Figure D1.}

Decline in Time and Demand Deposits During the 1933 Panic for Banks in 100 Cities

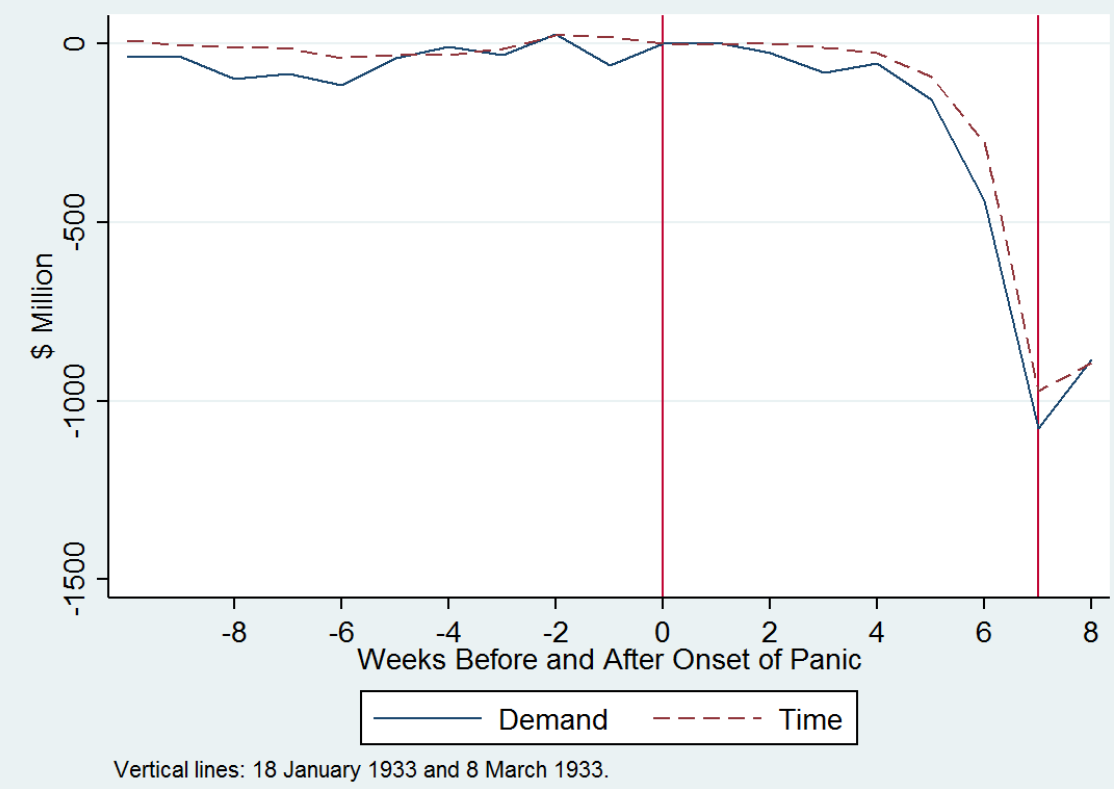

\section{Appendix Figure D2.}

Decline in Time and Demand Deposits in New York City Banks During the 1933 Panic

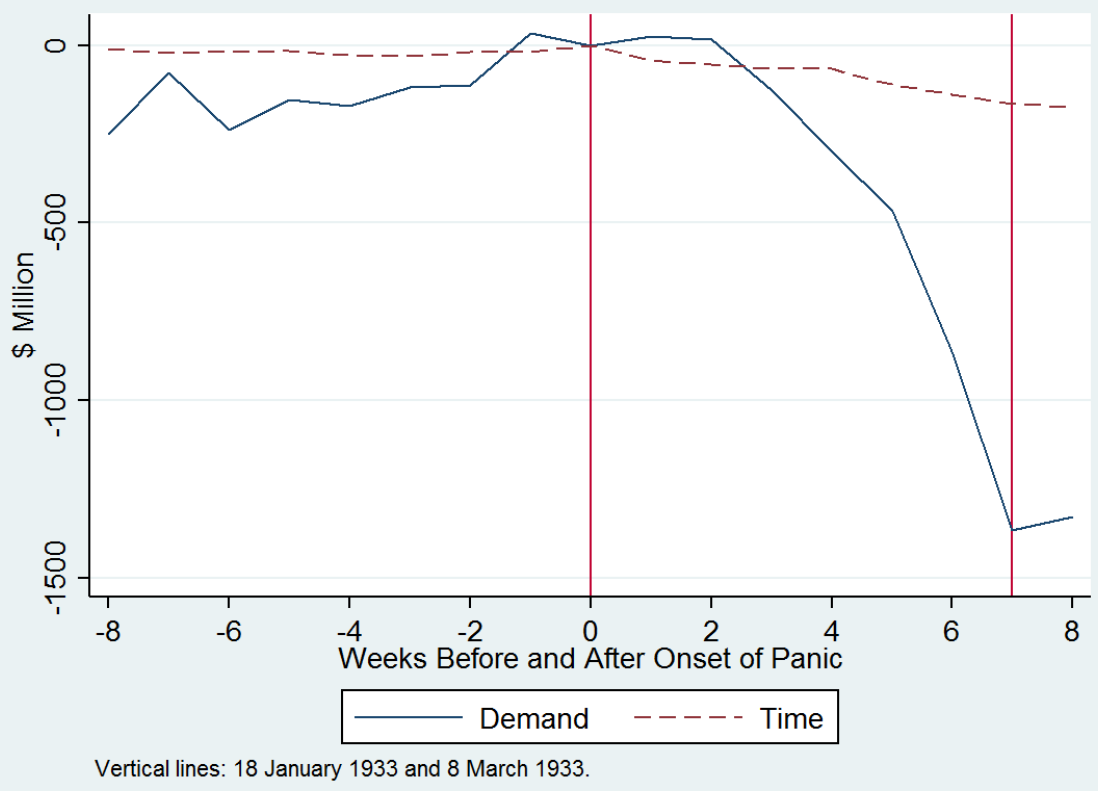

